\title{
Traduzir para criar: \\ literatura e ensino de projeto
}

\author{
Luís Antônio Jorge*
}

Resumo Destacadas obras literárias de Guimarães Rosa, Ferreira Gullar, García Marquez, Felisberto Hernández, Franz Kafka, Naoya Shiga, Alberto Ruy Sánchez, Italo Calvino, Georges Perec, Bartolomeu de Queirós, Mário de Andrade, Alcântara Machado, Adoniran Barbosa e Itamar Assumpção são interpretadas por meio de traduções: trabalho de natureza metalinguística ou crítico-criativo, desenvolvidas no âmbito da disciplina de TFG (Trabalho Final de Graduação) do Curso de Arquitetura e Urbanismo da FAU-USP. Também chamados de traduções intersemióticas, os exemplos apresentados são estudos sobre linguagem, com foco na função poética, como estratégia de desenvolvimento de projeto em um amplo espectro de atuação: arquitetura, design gráfico e de produto, cenografia e figurino.

Palavras-chave: ensino de projeto, tradução intersemiótica, literatura e arquitetura.

\section{Traducir para crear: literatura y enseñanza de proyectos}

Resumen Destacadas obras literarias de Guimarães Rosa, Ferreira Gullar, García Márquez, Felisberto Hernández, Franz Kafka, Naoya Shiga, Alberto Ruy Sánchez, Italo Calvino, Georges Perec, Bartolomeu de Queirós, Mário de Andrade, Alcântara Machado, Adoniran Barbosa y Itamar Assumpção son interpretadas por ejercicios de traducción: obra de carácter metalingüístico o crítico-creativo, desarrollada en el ámbito de los trabajos de finalización del curso de grado en Arquitectura y Urbanismo de la FAU-USP. También denominadas traducciones intersemióticas, los ejemplos presentados son estudios sobre lenguaje, con un enfoque en la función poética, como estrategia de desarrollo de proyectos en un amplio espectro de actividad: arquitectura, diseño gráfico y de producto, escenografía y vestuario.

Palavras clave: enseñanza del diseño, traducción intersemiótica, literatura y arquitectura.

\section{Translate to create: literature and project teaching}

Abstract Outstanding literary works by Guimarães Rosa, Ferreira Gullar, García Márquez, Felisberto Hernández, Franz Kafka, Naoya Shiga, Alberto Ruy Sánchez, Italo Calvino, Georges Perec, Bartolomeu de Queirós, Mário de Andrade, Alcântara Machado, Adoniran Barbosa and Itamar Assumpção are interpreted by translation exercises: work of a metalinguistic or critical-creative nature, developed within the scope of the completion of the degree course in Architecture and Urbanism at FAU-USP. Also called intersemiotic translations, the examples presented are studies on language, with a focus on the poetic function, as a project development strategy in a wide spectrum of activity: architecture, graphic and product design, scenography and costumes.

Keywords: design teaching, intersemiotic translation, literature and architecture. 
Entre lo que veo y digo,

Entre lo que digo y callo,

Entre lo que callo y sueño,

Entre lo que sueño y olvido

La poesía.

Se desliza entre el sí y el no:

dice

lo que callo,

calla

lo que digo,

sueña

lo que olvido.

No es un decir:

es un hacer.

Es un hacer

que es un decir.

Octavio Paz

(a Roman Jakobson)

* Luís Antônio Jorje é Arquiteto e Urbanista, Professor da Faculdade de Arquitetura e Urbanismo da Universidade de São Paulo, ORCID: <http://orcid.org/00000001-8276-0318>.
${ }_{-} Q$

ue catedrais tendes no pensamento? -indagava o professor Vilanova Artigas. Fazemos coro, provocando os alunos: quais são as obras da arte e do engenho humanos que vos formaram? Quem são vossos autores? Ao cabo de um curso como o da Faculdade de Arquitetura e Urbanismo e de uma vivencia universitária e cultural, na Universidade de São Paulo, na cidade de São Paulo e no mundo, quais são as vossas escolhas? Vossas afinidades eletivas? E por que tais obras ou autores calaram tão fundo em vós? O que eles vos ensinaram? Como construir um diálogo, de modo a repercutir tais preferências ou ideias em uma perspectiva de trabalho original e atual? Que passados respondem aos vossos presentes?

Na perspectiva que aqui se apresenta, o problema da tradução é uma estratégia para aprofundar o diálogo com estas afinidades espirituais, intelectuais ou estéticas, estimulando um ambiente de rigor investigativo, própria da profundidade requerida pela operação tradutória no âmbito dos estudos da linguagem.

O linguista Roman Jakobson, identificou três tipos de traduções, sempre invocadas nas nossas orientações: 1a. - a tradução intralinguística (ou reformulação) que consiste na interpretação dos signos verbais mediante outros signos da mesma língua; 2a. - a tradução interlinguística (a tradução no senso comum) que consiste na interpretação dos signos verbais por meio de algum outro idioma; 3a. - a tradução intersemiótica (ou transmutação) que consiste na interpretação dos signos verbais por meio dos sistemas de signos não verbais. Esta última é o tipo de tradução que move os trabalhos 
aqui comentados, onde a natureza das obras eleitas como referenciais para os alunos exige, fundamentalmente, estudos sobre a função poética da linguagem, ou seja, aquela que opera com as qualidades e informações de natureza estética ou icônica da mensagem. O difícil desafio de uma tradução intersemiótica é fazê-la, justamente, evidenciar a dimensão poética do texto original e, ambiciosamente, explorá-la para amplificá-la em novo figurino. O rigor, que em tal operação se impõe, advém de uma necessária análise de natureza metalinguística, quando se pressupõe que o sentido poético do texto original pode até se expressar melhor - ou expandir algumas das suas sugestões expressivas - em um novo sistema de signos ou em outro suporte material. Tal transmutação só pode se dar por relações de semelhança, por percepções de similaridades, por analogias descobertas entre formas (e não, entre conteúdos) e, por isso, ela não opera com igualdades ou equivalências pré-concebidas, como ensinou o livro Tradução Intersemiótica do professor Julio Plaza. Toda a atenção dirigir-se-á, neste tipo de interpretação que é a tradução, ao signo icônico, aquele que Charles Morris definiu como o que é de certa maneira similar àquilo que o denota. Haroldo de Campos criou a aguda metáfora da rosácea das convergências para abordar a sincronia que aproxima e relaciona manifestações poéticas distantes no tempo e no espaço. Os poetas Décio Pignatari e os irmãos Haroldo e Augusto de Campos teorizaram e praticaram a tradução no âmbito da poesia, nomeando-a como transcriação. Nesta esfera, exerceram o pleno ofício político dos seus legados estéticos.

O agrupamento de Trabalhos Finais de Graduação (TFGs) apresentados a seguir, resulta de uma similaridade de abordagem e de um mesmo referencial teórico. Formado por interesses e objetos de estudo muito diferentes entre si, eles têm em comum, primeiramente, uma forma de trabalho definida pelas operações tradutórias, invariavelmente, entre sistemas de linguagens distintos ou intersemióticas; e em segundo lugar, a literatura como campo de investigação e fonte inspiradora. Paradoxalmente, a troca coletiva de informações e ideias, nos grupos que se formam, anualmente, é das mais ricas e produtivas: as preferências e as propostas individuais enriquecem a sensibilidade coletiva e o vínculo comum que é, fundamentalmente, de natureza metodológica. 
Figura 1: Páginas de TFG/FAU.USP "Ilustrações para um conto de João Guimarães Rosa (2011)" de Sandra Maria Lorenzon Jávera. Fonte: Acervo do autor.
Ilustrações para um conto de João Guimarães Rosa (2011) de Sandra Maria Lorenzon Jávera iniciou-se como pesquisa sobre brinquedos, sobretudo, sobre a arte ou os artistas que flertam com os brinquedos: Calder, Torres García, Klee, Picasso, Sophie Tauber-Arp, Alma Sieddhoff-Buscher, Luigi Veronesi, Hanna Höch, Rodtchenko e Isidro Ferrer. As discussões sobre a dimensão lúdica e os desenhos de ilustradores e artistas com evidentes traços que remetem ao universo da criança pautaram uma série de expressões experimentais que acabaram por definir o produto final: a concepção e produção de um livro ilustrado para uma obra literária. O conto Partida do Audaz Navegante, do livro Primeiras Estórias do escritor João Guimarães Rosa, pareceu-nos reunir os elementos poéticos buscados e o espírito do trabalho desejado.

Denomina-se este tipo de tradução intersemiótica de transposição, pois ela conservará os signos do texto original, preservando-o na sua integridade verbal e semântica, para acolhê-lo em outro suporte, elaborado como um trabalho interpretativo em chave criativa. A primeira das operações acionadas neste tipo de trabalho com a literatura é o garimpar das palavras: a retirada da pedra bruta da sua existência mineral para, isolada, virar pepita, preciosidade sensitiva em expansão significativa.

Na manhã de um dia em que brumava e chuviscava, parecia não acontecer coisa nenhuma.

Trata-se da primeira frase do conto, que no projeto foi isolada em página dupla duplicando o formato "paisagem" do livro - e sobreposta a uma imagem de um lusco fusco em tons de cinza, gotas luminosas numa paisagem nublada, sem definição. Só bruma, chuvisco e nada de acontecimento. 
Sucede o mesmo com a frase: Nurka, negra, dormia.

Figura 2: Páginas de TFG/FAU.USP "llustrações para um conto de João Guimarães Rosa (2011)" de Sandra Maria Lorenzon Jávera. Fonte: Acervo do autor.
Isolada, oferece uma dimensão superlativa ao personagem canino, então figurante, compondo o cenário entre intrigantes personagens infantis. É preciso ouvir os silêncios do texto de Rosa, assim como se esgueirar ou correr desabaladamente, segundo os múltiplos ritmos e todas as suas variabilidades sonora e imagética.

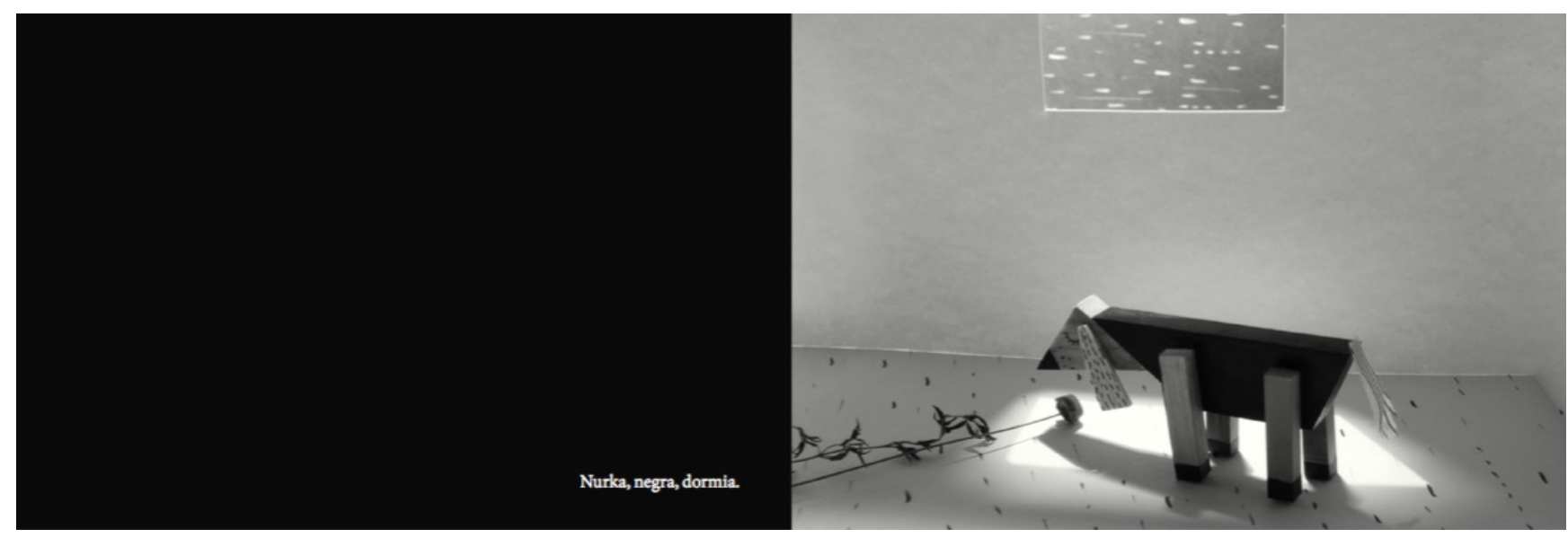

risCO. v19_2021 - Edição Temática "Desenho" 


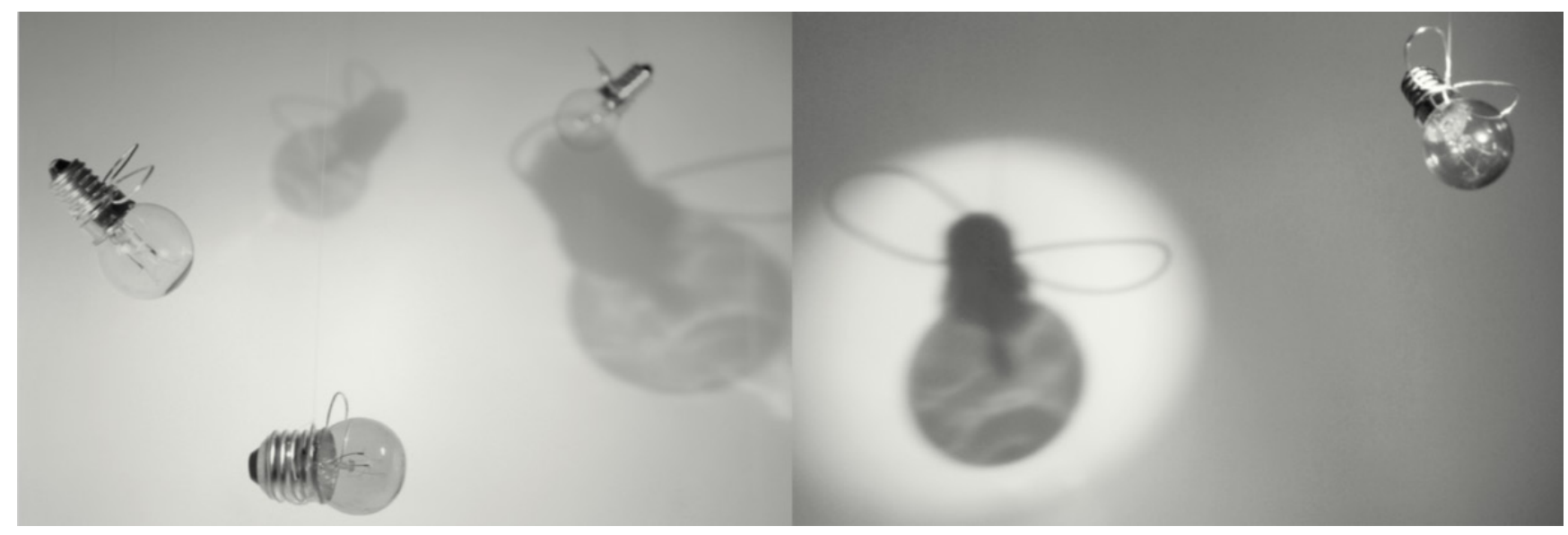

Figura 3: Páginas de TFG/FAU.USP "Ilustrações para um conto de João Guimarães Rosa (2011)" de Sandra Maria Lorenzon Jávera. Fonte: Acervo do autor.
A imitação da forma é uma expressão cunhada pelo professor João Alexandre Barbosa para explicar a poética do João Cabral de Melo Neto que, segundo ele, realiza uma poesia que não imita conteúdos da realidade, mas imita formas, o que explica, porque todas as linguagens de artes diferentes servem aos propósitos do poeta. Este procedimento define a segunda das operações a destacar no trabalho de tradução, sobretudo, de um autor como Guimarães Rosa. O que equivaleria, no campo formal, às palavras ou expressões (neologismos?) como diligentil, ciumoso, infimículas inquietações, Brejeirinha rebica, picuíca..., o rio, grossoso, se descomporta, e o riachinho [...] pororoqueja. Toda sorte de coisas imaginadas com as suas qualidades tão inusitadas, participando de ações de personagens sempre reflexivos, filosofantes da banalidade da vida e dos seus espasmos extraordinários.

Como Guimarães Rosa fala da criança que ainda não sabe narrar? Uma narrativa repleta de invencionices ainda que prejudicada no plano do significado. Rosa parece querer nos ensinar a imitar a fantasia da imaginação infantil. Uma nova linguagem em narrativa descomposta? Como imitar, então, a forma do vagalume? 
Figura 4: Páginas de TFG/FAU.USP "llustrações para um conto de João Guimarães Rosa (2011)" de Sandra Maria Lorenzon Jávera. Fonte: Acervo do autor.
Agora eu sei. O Aldaz Navegante não foi sozinho; pronto! Mas ele embarcou com a moça que ele amavam-se, entraram no navio, estricto. E pronto. O mar foi indo com eles, estético. Eles iam sem sozinhos, no navio, que ficando cada vez mais bonito, mais bonito, o navio... pronto: e virou vagalumes...

Os sons murmurantes do amor e do mar, na sequencia de fonemas bilabiais que conduzem, em vento, a embarcação do solitário e imaginado personagem são os elementos formais operados na imagem a seguir: movimento navegante, velocidade lenta do vento e o giro lunar.

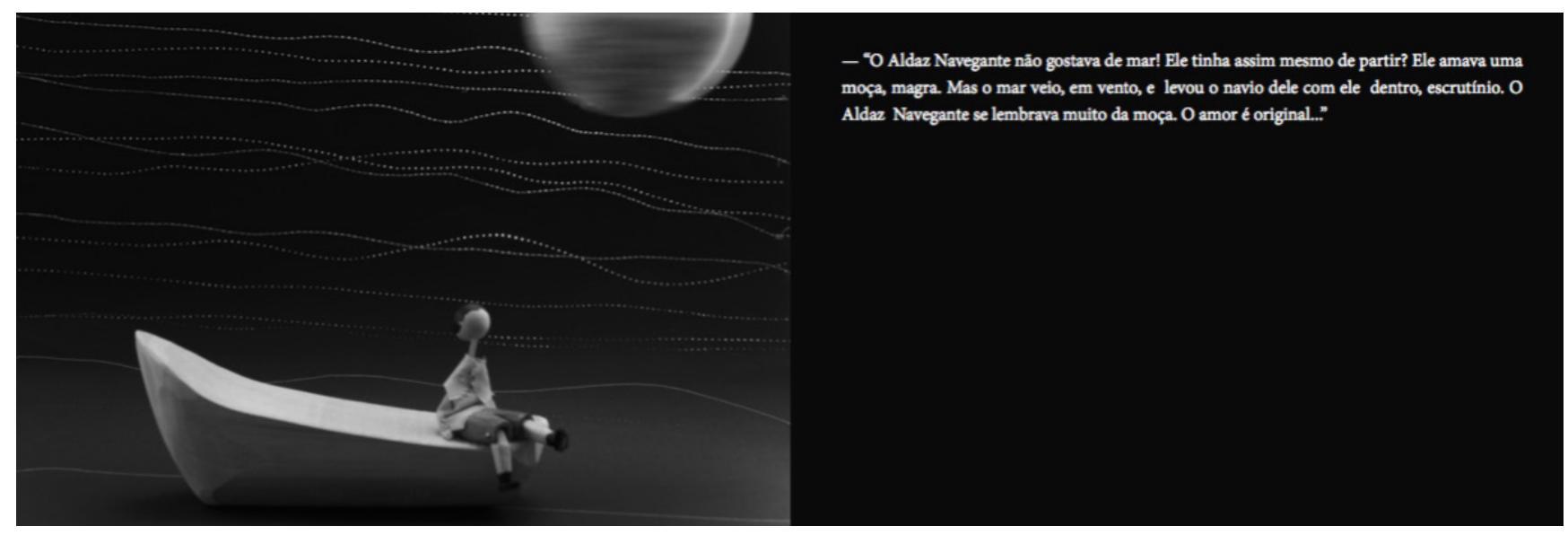

risCO. v19_2021 - Edição Temática "Desenho" 
Zito não respondia, desesperado de repente, controversioso-culposo, sonhava ir-se embora, teatral, debaixo de chuva que chuva, ele estalava numa raiva.

Mas Brejeimnha tinha o dom de apreender as tenuidades: delas apropriava-se e refletia-as em si - a coisa das coisas e a pessoa das pessoas. - "Zito, você podia ser o pirata inglório marujo, num navio muito intacto, para longe, lo-õ-onge no mar, navegante que o nunca-mais, de todos?" Zito sorri, feito um ar forte. Ciganinha estremecera, e segurou com mais dedos o livro, hesitada. Mamãe dera a Pele a terrina, para ela bater os ovos.

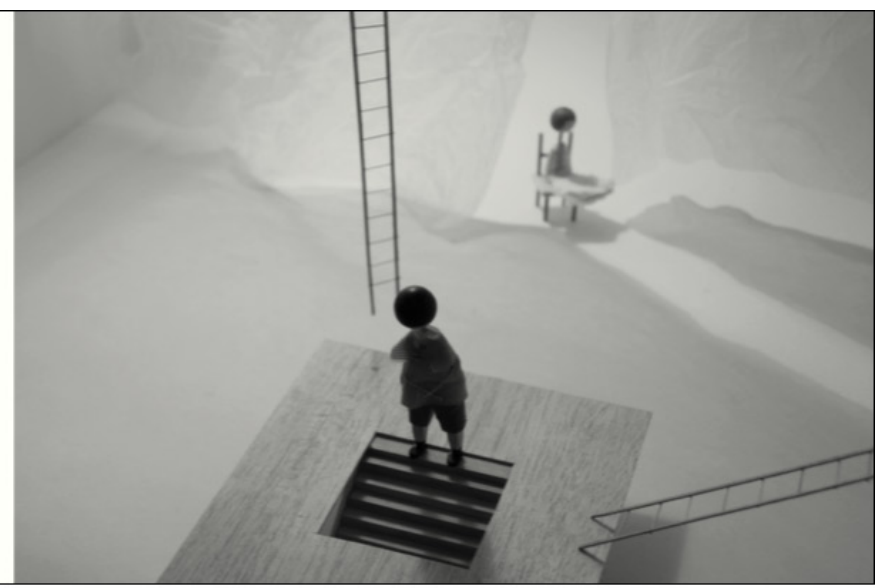

Figura 5: Páginas de TFG/FAU.USP "llustrações para um conto de João Guimarães Rosa (2011)" de Sandra Maria Lorenzon Jávera. Fonte: Acervo do autor.
Os recursos e os meios utilizados na composição das imagens do livro foram: a criação de bonecos físicos dos personagens (objeto inicial do trabalho da aluna); a concepção de cenários sem fechos, sem arestas entre piso e paredes, para retratar uma atmosfera onírica e uma paisagem fugidia, definida, minimamente, pela figuração de elementos dispersos numa espacialidade infinita; a iluminação como recurso retórico adicional desta espacialidade concebida; a fotografia como meio de representação principal; e, por fim, o tratamento gráfico do desenho digital.

Procurou-se flagrar a dimensão metafísica da literatura de Rosa, com seus paradoxos e enigmas indecifráveis ("Mamãe, agora eu sei, mais: que o ovo só se parece, mesmo, é com um espeto"). 
Figuras 6 e 7: Transcrição de "Poema Sujo" de Ferreira Gullar (1975). In: TFG/FAU.USP Corpo e Espaço: a transcriação em sete narrativas literárias (2012) de Marina Prado Sander Smit. Fonte: Acervo do autor.
Em Corpo e Espaço: a transcriação em sete narrativas literárias (2012) de Marina Prado Sander Smit, a seleção de textos literários constitui uma tessitura de relatos onde o corpo é sempre personagem central, mas em diferentes contextos espaciais e existenciais. Pretende-se com isso, um diálogo intertextual a desenhar um mosaico, mais imaginário que imagético, onde a relação corpo/espaço forneça matéria poética para o exercício de criação (design) e de interpretação poética. Novamente, para acentuar as características icônicas ou estéticas dos contos ou poemas selecionados, estes foram transcritos integralmente nos objetos projetados: um novo corpo-espaço do texto literário. Como observou Julio Plaza, no já citado "Tradução Intersemiótica", a escolha do que será traduzido obedece a um projeto criativo e a uma afinidade estética, a uma espécie de ressonância movida pelos princípios da analogia.

Começando por um trecho do Poema Sujo de Ferreira Gullar (1975), onde o corpo é tratado ora como coisa percebida no espaço, ora como corpo sensitivo, oscilando entre os pontos de vista exterior (que é visto) e interior (que vê e que sente). Ambas as perspectivas tratam do corpo e do sentimento sofridos pelo poeta exilado e a tradução procura explorar a sensação de dor e de violência retratada no poema. Para tal, o tato do papel utilizado provoca sensação semelhante ao toque na própria pele, agora suturada por pontos que criam relevos para moldar o corpo da palavra escrita.
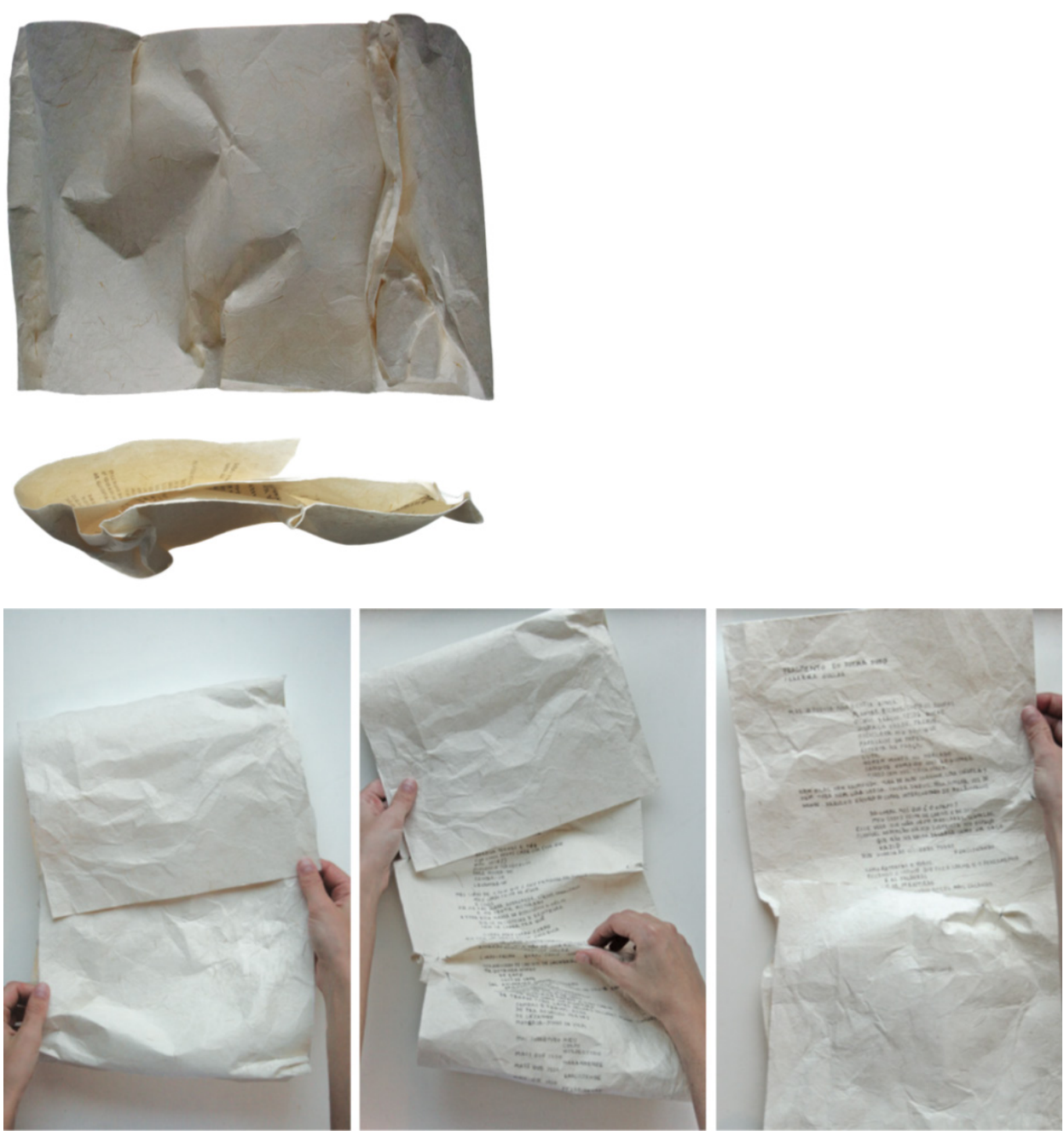
Figura 8: Transcrição de "O Afogado mais bonito do mundo", de Gabriel García Márquez (1968). In:TFG/FAU.USP Corpo e Espaço: a transcriação em sete narrativas literárias (2012) de Marina Prado Sander Smit. Fonte: Acervo do autor.

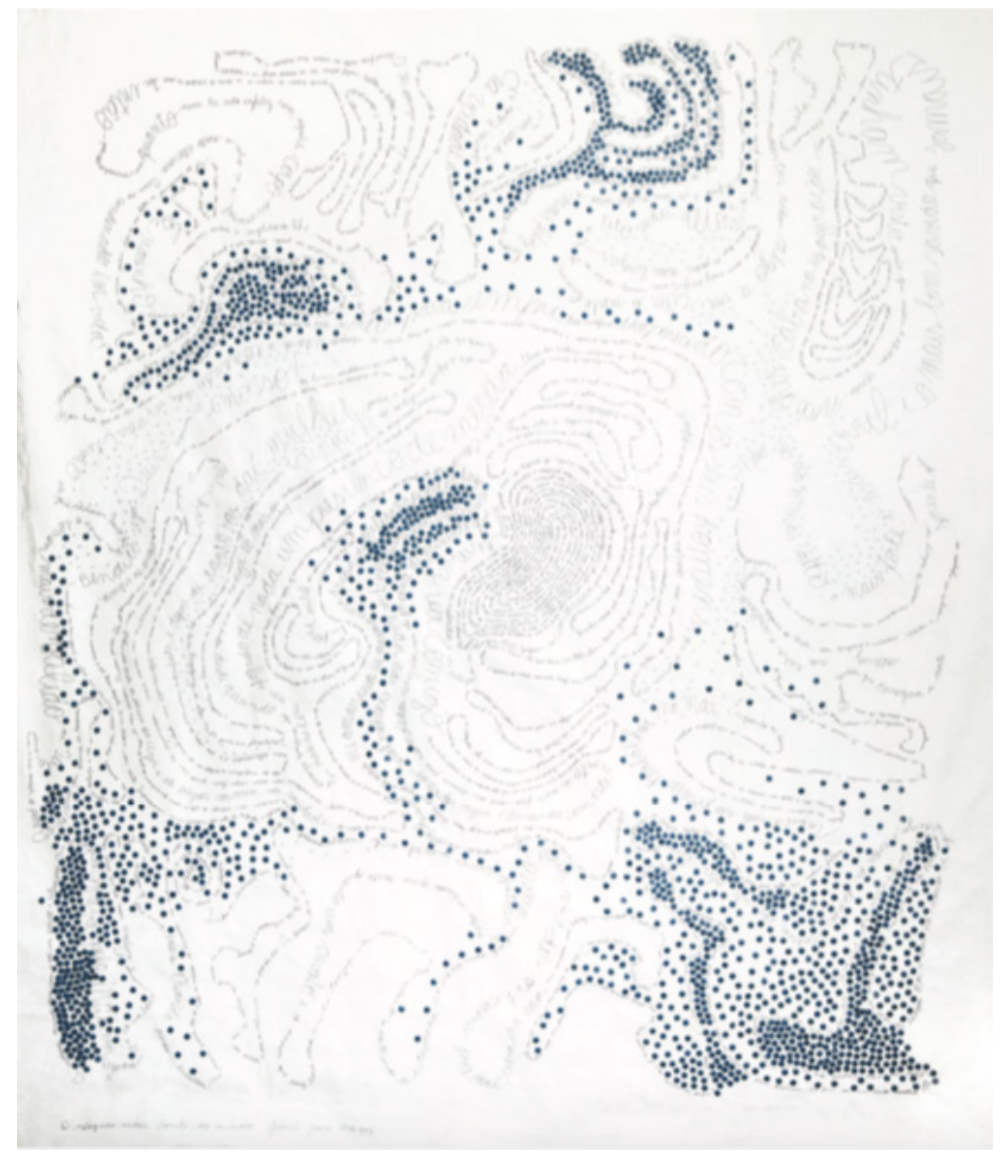

Em um tecido sintético, à guisa de um grande mapa para ser estendido no chão, foi reescrito, na íntegra, o conto O Afogado mais bonito do mundo, de Gabriel García Márquez (1968). A caligrafia busca reconhecer as entonações e alturas sonoras do texto, percorrendo linhas ondulantes como curvas de nível de uma imaginária carta topográfica, que se completa pela inscrição de tachinhas azuis perfurando o tecido, ora em um sentido (para cima), ora em outro (para baixo). O azul das tachinhas metálicas remete à cor do mar e a paisagem marítima da aparição do protagonista cadáver do conto de Márquez. O corpo do leitor precisa se mover, contornando o mapa-texto e contorcendo-se para percorrer o novelo descrito pela escrita, aludindo à uma representação técnica do relevo do território muito familiar aos arquitetos (os levantamentos planialtimétricos), mas também aos navegadores, pois a variação do corpo do texto, lembra o movimento das correntes marítimas e a ação do vento (as cartas náuticas). O mapa, suporte do conto, pelas suas dimensões exageradas transmite a desproporção do corpo descomunal do cadáver que espantou aqueles que o encontraram na praia. O manto, com as afiadas pontas metálicas também lembra a malha de armaduras medievais e dificulta o manuseio, sem repelir, propriamente, a "tatilidade" evocada pelo olhar seduzido pelos materiais que o compõem. 
Figura 9: Transcrição de "Ninguém acendia as luzes", de Felisberto Hernández (1947). In: TFG/FAU.USP Corpo e Espaço: a transcriação em sete narrativas literárias (2012) de Marina Prado Sander Smit. Fonte: Acervo do autor.
A caixinha preta que contem o conto Ninguém acendia as luzes, de Felisberto Hernández (1947), é construída como uma gaveta de onde se retira um folha de papel delgada e semi-translúcida, onde o texto aparece sobre uma trama de linhas embaraçadas, como se resultassem de uma action painting. O papel fora carimbado inúmeras vezes para criar uma epiderme finamente texturizada, apelando ao sentido tátil, no manuseio necessário para a leitura. O narrador deste conto está na sala da casa de uma viúva, provavelmente velando pelo seu marido. Ele descreve atentamente as características dos cabelos dos demais presentes, como se cada um pudesse ser definido pela suas respectivas cabeleiras. Detem-se na jovem dos cabelos ondulados, atraído pelos fios que se espalham pela parede na qual ela está recostada, imaginando-a como uma grande galinha, cujo cabelo se assemelha a um tipo penas muito finas. A transcriação aqui realizada remete a esta cabeleira ondulada, representada pela cor vermelhas e exige, do leitor, uma atenção para que se perceba a imagem do carimbo em forma de galinha que deu origem a trama.
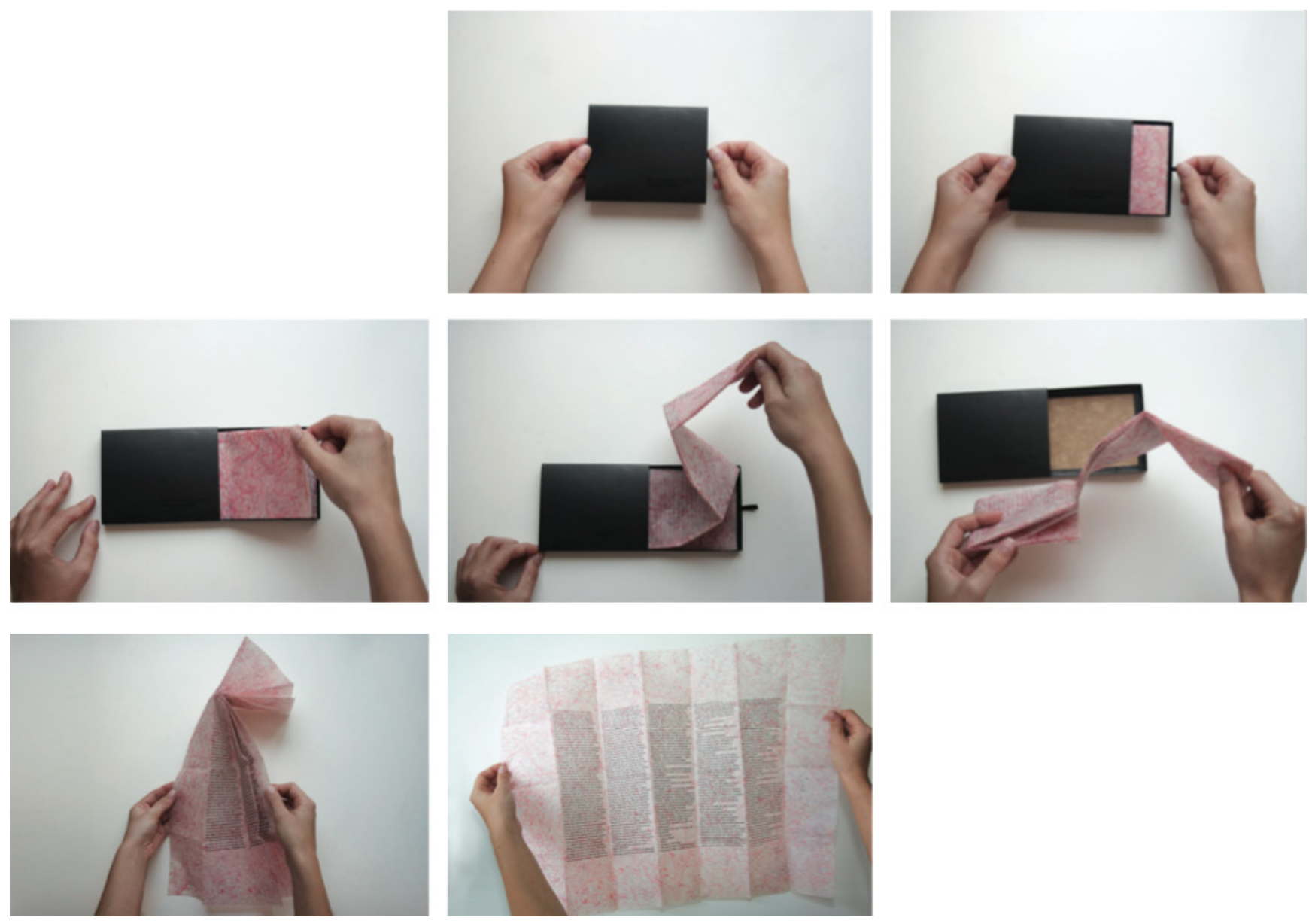
Figura 10: Transcrição de "Primeira Dor", de Franz Kafka (1922). In: TFG/FAU.USP Corpo e Espaço: a transcriação em sete narrativas literárias (2012) de Marina Prado Sander Smit. Fonte: Acervo do autor.
Nos quatros contos restantes deste TFG, percebe-se uma relação intertextual entre dois pares, explicitada por meio da escolha dos materiais utilizados nos objetos transcriados, que aproximam os contos Primeira Dor, de Franz Kafka (1922) e $\boldsymbol{A}$ morte da mulher do atirador de facas, de Naoya Shiga (1913), assim como o conto El Jardín de Nubes, de Alberto Ruy Sánchez (2001) do conto As cidades e as trocas, de Italo Calvino (1972). Em todos eles, procura-se fazer a passagem do corpo retratado como matéria física, para o corpo como consciência, ao fim, derrotado, no espaço cenográfico e permanente.

No conto de Kafka, os personagens circenses compartilham a angústia do homem inseguro, preso ao um mundo fechado, repleto de dúvidas e incertezas. O trapezista de Kafka possui a obsessão de atingir a perfeição na sua arte que resume o seu mundo. Tocar o chão é impensável e a vida só se realiza no topo do picadeiro: dedica-se obsessivamente ao aperfeiçoamento de uma mesma técnica, até o momento em que percebe não ser isso suficiente, quando exige mais um trapézio. A crise existencial do trapezista abala também seu empresário, que percebe, naquele corpo ainda jovem, as primeiras marcas da angústia e da preocupação. Na transcriação realizada, o texto foi impresso em placas retangulares de cobre, com $7 \times 21 \mathrm{~cm}$, que são mantidas suspensas por um eixo perpendicular a elas, dentro de uma caixa, uma rígida carapaça. Assim como o trapezista, as placas não tocam o chão e pendulam em torno do eixo. As paredes espessas desta estrutura protegem as finas folhas de cobre, em processo de oxidação contínua ao longo do tempo. O conjunto de placas deve ser retirado do interior da luva-carapaça para a leitura. Ao pendular as placas para leitura do conto, reproduz-se, o movimento do trapézio. A escolha de materiais remete ao circo: seu interior é revestido com um padrão colorido, azul e vermelho, sendo o exterior recoberto por um papel bastante rígido, com textura que lembra uma couraça, que tem em si algo de animalesco e selvagem.

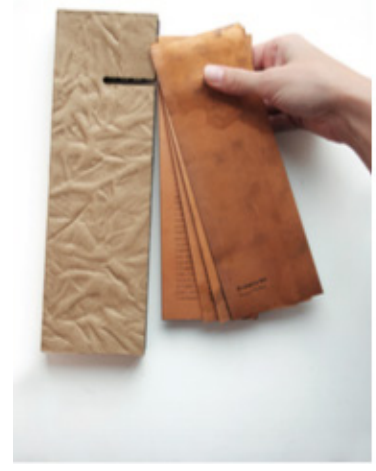

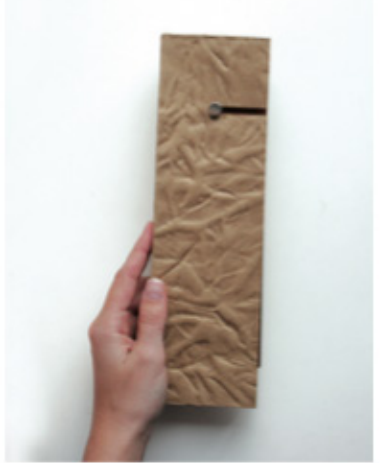
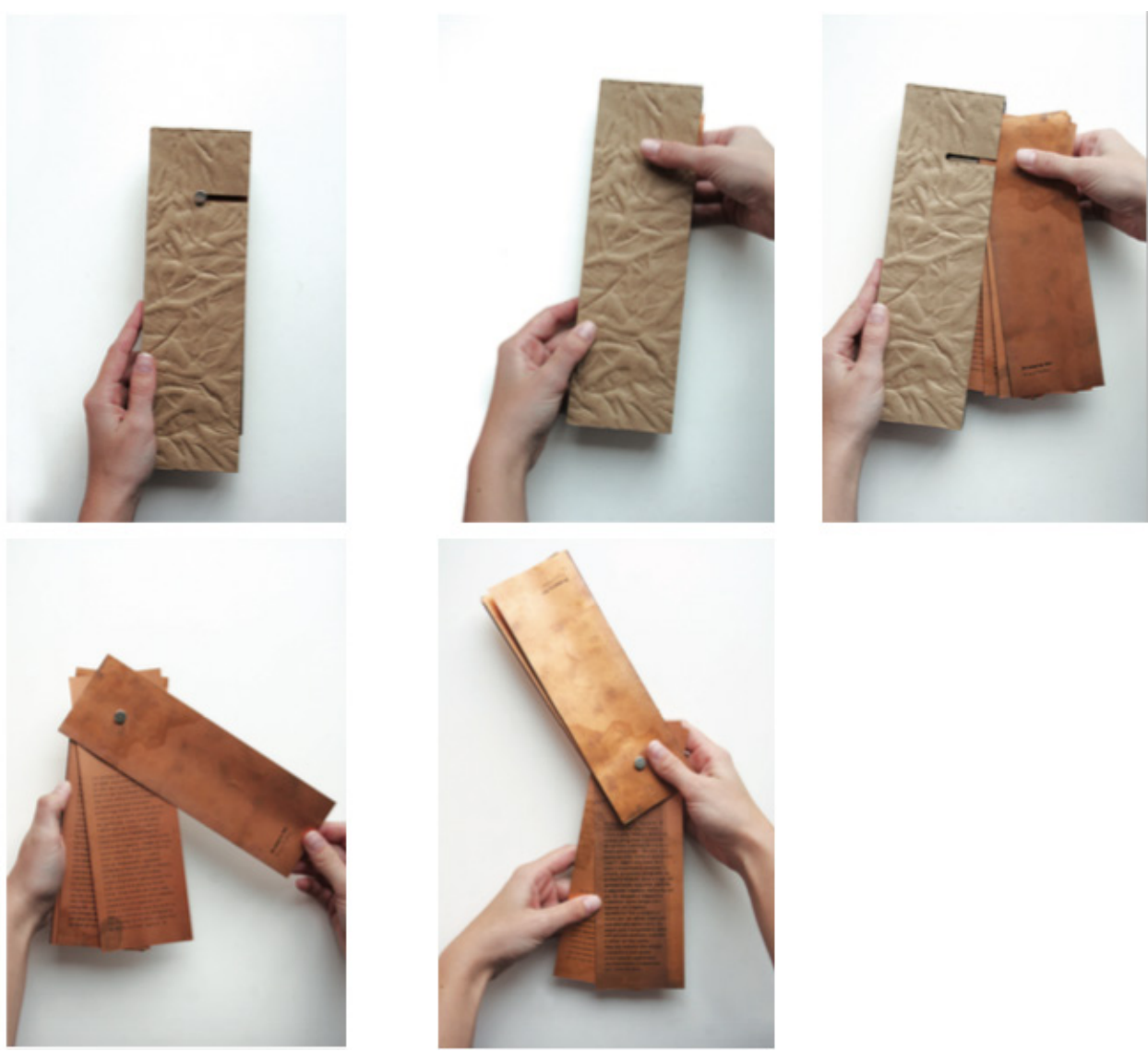

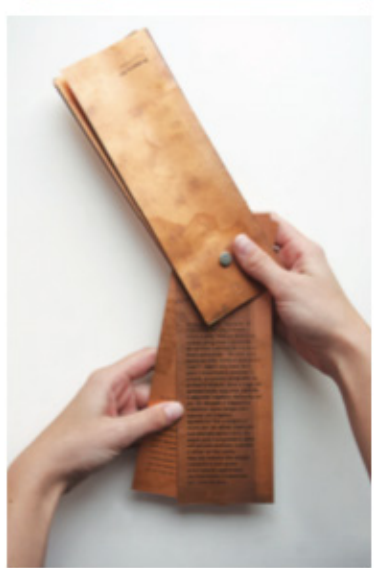



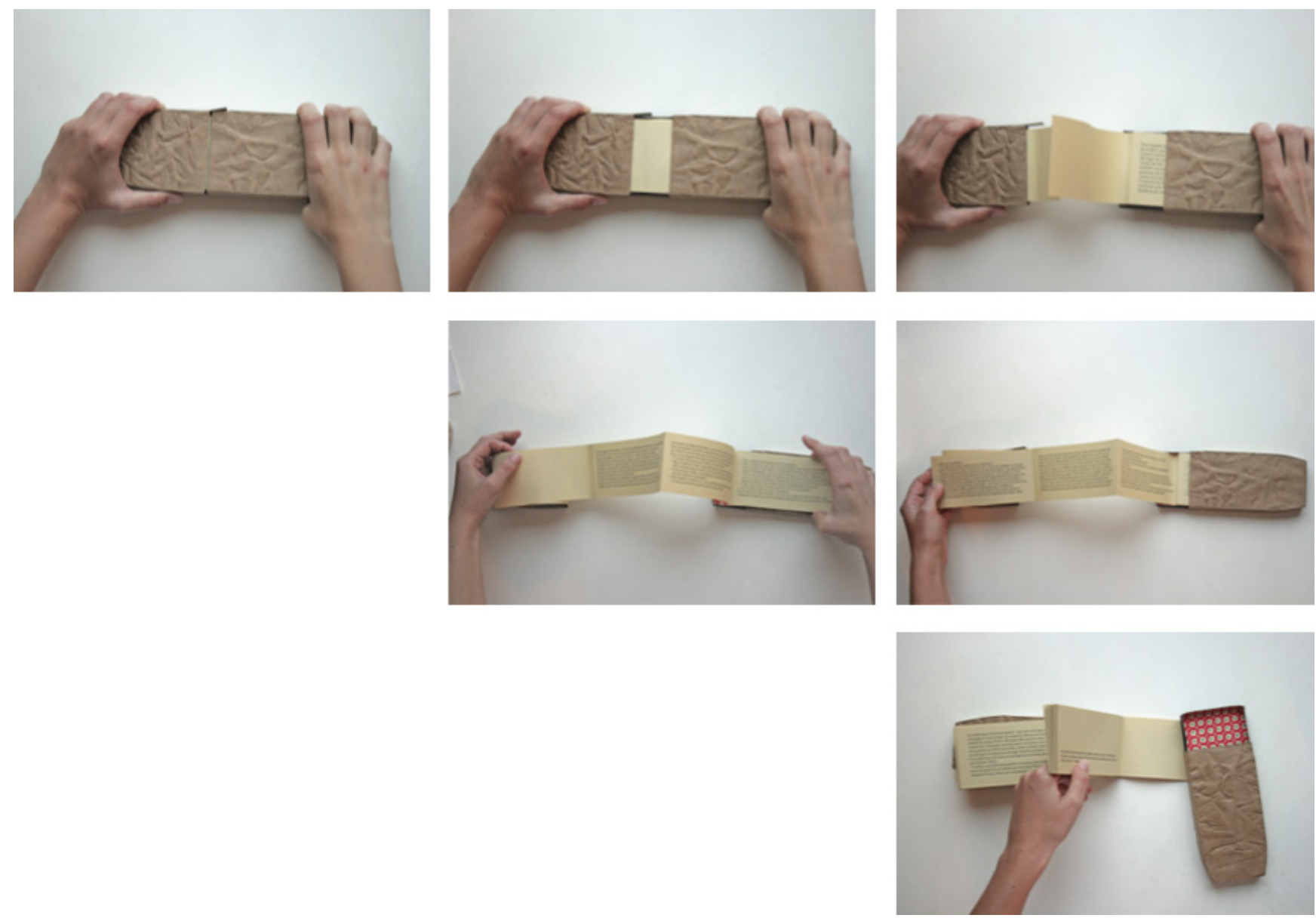

Figura 11: Transcrição de "A morte da mulher do atirador de facas", de Naoya Shiga (1913). In: TFG/FAU.USP Corpo e Espaço: a transcriação em sete narrativas literárias (2012) de Marina Prado Sander Smit. Fonte: Acervo do autor.
Em $\boldsymbol{A}$ morte da mulher do atirador de facas, acompanha-se o julgamento de Han, artista de circo, atirador de facas que mata, durante o espetáculo, a sua mulher e parceira no show. A narrativa vasculha as suspeitas, as dúvidas, as incertezas do ocorrido: culpado ou inocente? Imperícia ou propósito? Um homem desiludido no amor, sabido traído, do que é capaz de fazer? O próprio atirador de facas não sabe responder, oscilando entre a dimensão do consciente e do inconsciente. A tradução busca reproduzir no manuseio do objeto criado o espaço desta tensão. O conto fica guardado dentro de uma caixa, como um punhal em sua bainha. A transcrição foi feita em uma grande faixa de papel, modulada, dobrada, em pequenas páginas. Para a leitura, é necessário segurar a tampa e puxar, aos poucos, o texto do interior da estrutura. O gesto simula a retirada da faca da bainha e o atrito da faixa de papel, ao ser exposto, produz uma sonoridade análoga ao gesto real ou ao voo das facas. Módulos em branco são introduzidos no texto, ao final do conto, atrasando o desfecho da história, a revelação do veredicto, acentuando a tensão. Os materiais escolhidos para a confecção da bainha conectam este conto ao que o antecede, enfatizando a relação entre os dois textos: narrativas que retratam a angústia do corpo, as experiências dos artistas de circo, e, vistos no conjunto dos textos escolhidos, são uma pausa antes do corpo perder-se no espaço labiríntico e transitório, representados nos dois últimos contos. 
Figura 12: Transcrição de "El Jardín de Nubes", de Alberto Ruy Sánchez (2001). In: TFG/FAU. USP Corpo e Espaço: a transcriação em sete narrativas literárias (2012) de Marina Prado Sander Smit. Fonte: Acervo do autor.
O jardineiro narrado em El Jardín de Nubes é um corpo-que-não-alcança, impotente e pequeno em meio ao deserto em que vive. Inspirado em uma lenda chilena que ouvira, o personagem não mede esforços para acumular água suficiente para cultivar uma preciosidade: seu jardim. Mesmo construindo uma torre cada vez mais alta, não alcança as nuvens para realizar seu propósito. O objeto que traduz este texto mostra a dimensão do espaço nunca vencido e do esforço que ele exige do corpo do protagonista. O módulo triangular - uma referência à 'rede de triângulos invertidos' que o personagem manda fabricar - que orienta as dobraduras no papel pergaminho, a partir de uma série de progressão harmônica, geometricamente infinita, impõe que o corpo do texto vá se constrangendo até o limite da legibilidade, simulando uma fala cada vez mais distante.
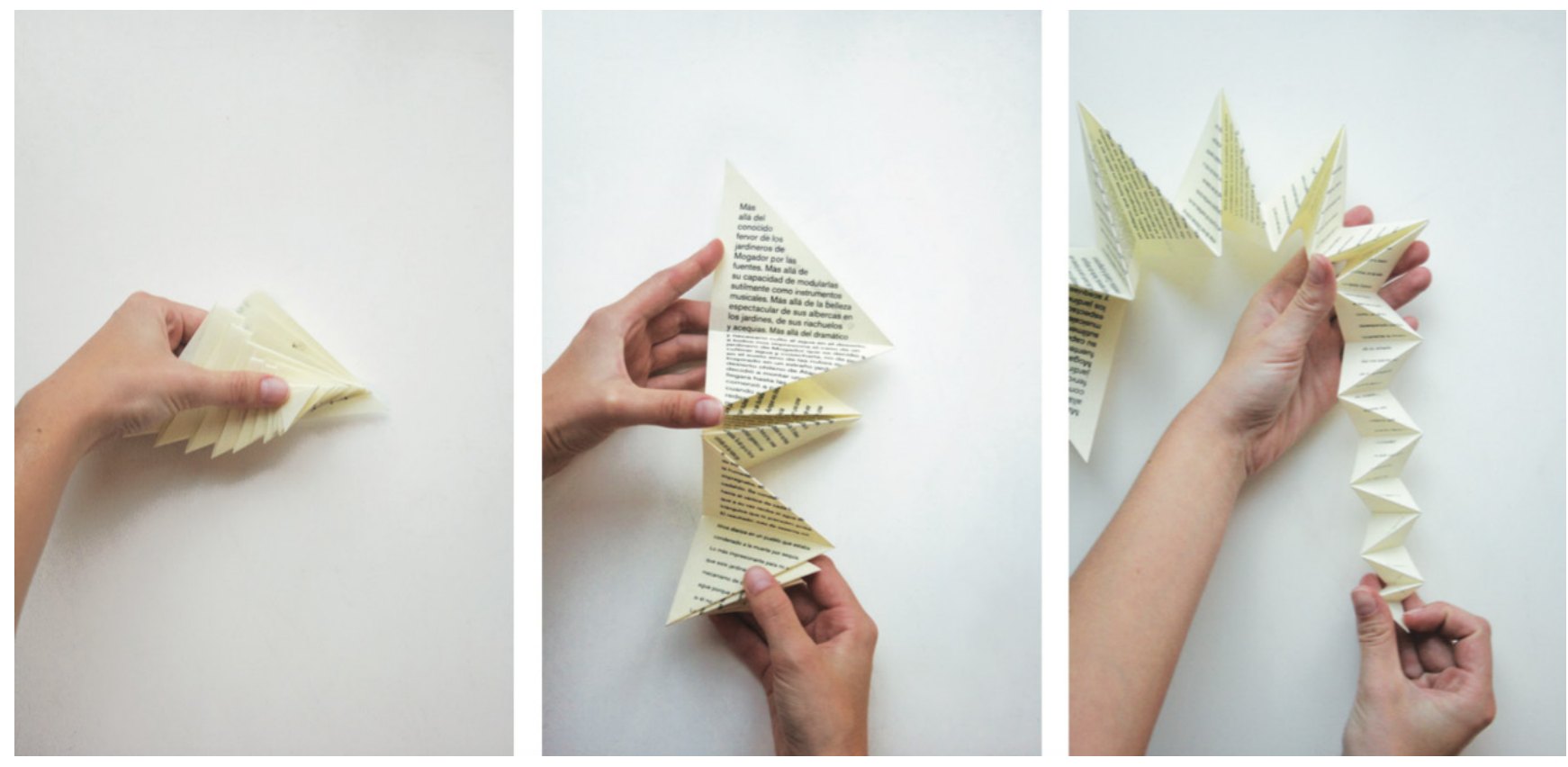

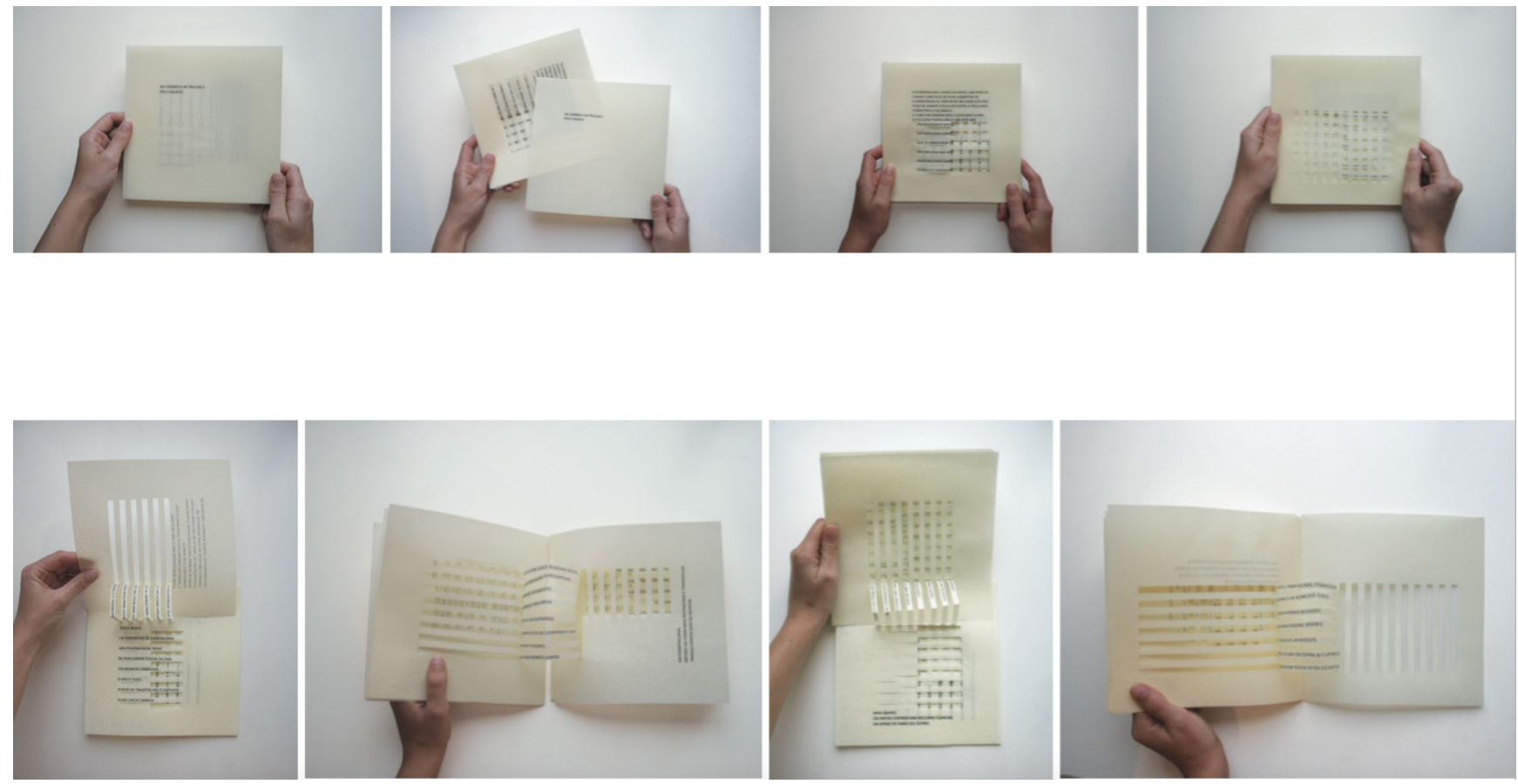

Figura 13: Transcrição de "As cidades e as trocas", de Italo Calvino (1972). In: TFG/FAU. USP Corpo e Espaço: a transcriação em sete narrativas literárias (2012) de Marina Prado Sander Smit. Fonte: Acervo do autor.
Já, no referido conto de Calvino, o corpo aparece apenas para descrever o espaço de maneira percorrido. As relações humanas são secundárias, diante a descrição espacial. O que é apreendido do texto são as inúmeras camadas, passagens e caminhos traçados em Esmeraldina. A tradução é feita com folhas quadradas de pergaminho, levemente translúcido, justapostas, unidas por recortes que conduzem o texto e o faz transitar do bidimensional ao tridimensional. O texto-objeto percorre diferentes camadas, demonstrando as possibilidades espaciais descritas e imaginadas. O objeto, para sua leitura, precisa ser manipulado de forma que componha um giro. O movimento de alguém inserido em um espaço, olhando ao redor, é reproduzido pelo leitor deste objeto que visita Esmeraldina, com seus fossos, esgotos, vielas, escadas, ruas suspensas, pontes e bailéus, agora em um suporte labiríntico que acolhe a expressão poéticaespacial do texto de Calvino. 
O TFG de Cristina Myung Sun Gu, Disforia Urbana e os Espectros do Anonimato na Metrópole Contemporânea (2012) foi selecionado para ser publicado no site do FPO (For Print Only) - Graduation Project, cujo curador é Duncan Robertson, que assim justificou sua escolha;

This thesis project experiments with George Perec's "A Man Asleep" through multiple modes of interpretation-typography, layout, editing, production, etc. The original second-person novel is divided into three parts, which are each represented by one of three books in the set. For Cristina Myung Sun Gu each design decision provided another angle for interpreting and relaying the story.

O reconhecimento da qualidade deste trabalho foi ampliado por integrar a exposição Édition I Forme I Expérimentation, formada por cerca de 60 livros de artista, selecionados em todo o mundo, a cargo do Collectif Blanc / Galerie UQO, Montreal, Canadá, entre 24 de fevereiro e 24 de março de 2016.

O título do trabalho destaca aspectos da condição existencial do homem na metrópole - com estudos que bebem em autores como Georg Simmel, Walter Benjamin, David Harvey, Gilles Lipovetsky, Michel Foucault, Vilém Flusser, Richard Sennett, Anthony Vidler, entre outros - para encontrar, na obra do escritor francês Georges Perec, Un homme qui dort (1967), uma espécie de representação poético-simbólica deste estado de coisas que definem a condição humana estudada. Este romance deu luz a um filme, longa metragem, homônimo, dirigido por Bernard Queysanne (1974) que serviu como análise sobre a experiência de uma tradução intersemiótica contida na passagem da literatura para o cinema, com especial atenção à dimensão poética, ou seja, a forma fílmica resultante. Posteriormente, uma nova imersão no romance de Perec destacou as passagens mais representativas da condição existencial do personagem que conduz a narrativa para serem transpostos em um "livro de artista", um objeto tripartido nas seguintes peças intituladas: "Homem Ostra", "Multidão" e "Percursos", concebidas e confeccionadas por diferentes formas narrativas, técnicas de impressão e suportes materiais, com um cuidado e esmero de uma designer e artesã.

Este TFG é um trabalho exemplar para demonstrar o ofício da transcriação: a apreensão da textura poética das palavras transportadas para a dimensão tátil-visual do papel impresso, com suas variadas epidermes, opacidade ou translucidez, peso ou espessura; a absorção dos ritmos variados da narrativa, ora ligeira, feitas de palavras curtas, como em "Percursos", geometricamente dispostas em colunas de tipos brancos sobre o fundo negro, demarcando vias (de leitura) urbanas, percursos pela cidade descrita, despida e devastada, na imaginação do personagem solitário e do leitor que o acompanha em sua caminhada a esmo; a imersão nos sons aprisionados nas palavras, ora sussurradas, ora enfáticas, como as respostas afirmativas ou as reiterações, presentes em um texto de uma linha sem fim, acondicionado em suporte sanfonado - como em "Multidão" - sobre um fundo de cor oscilante, ora negro, ora claro, da cor natural do papel arroz oriental, à semelhança de quem lê um texto cujo fundo é um céu com os movimentos surpreendentes das nuvens; e por fim, a expressão dos sentidos das escolhas, tão arbitrárias quanto precisas, demonstrando que a atividade da leitura não se encerra em um sentido final, mas ao contrário, quanto mais profunda e mais distante dos automatismos próprios do mundo verbal, mais aberta à grandeza libertária da poesia. 


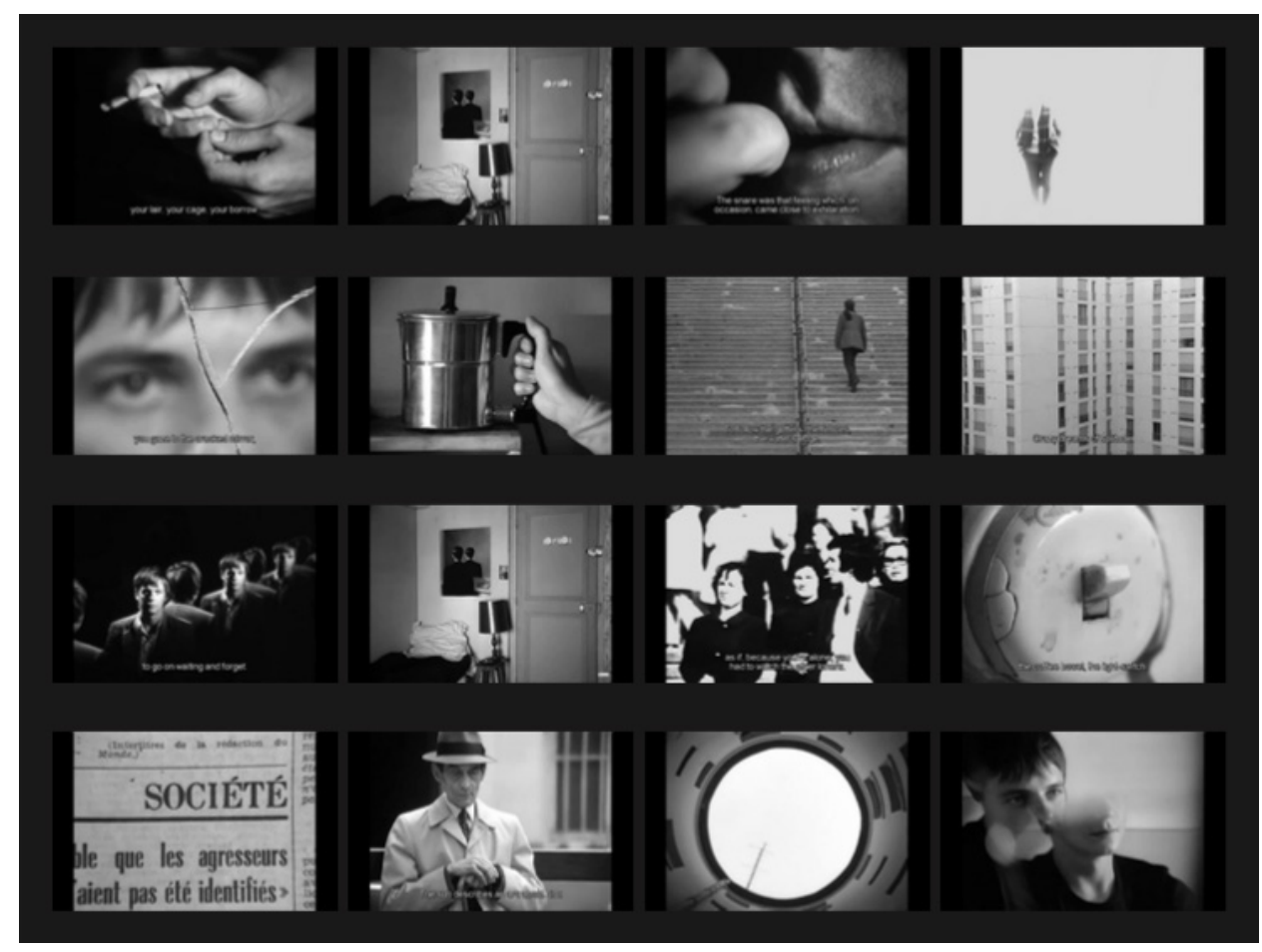

Figura 14: Seleção de cenas do longa metragem "Un homme qui dort", dirigido por Bernard Queysanne (1974). In: TFG/FAU.USP Disforia Urbana e os Espectros do Anonimato na Metrópole Contemporânea (2012) de Cristina Myung Sun Gu. Fonte: Acervo
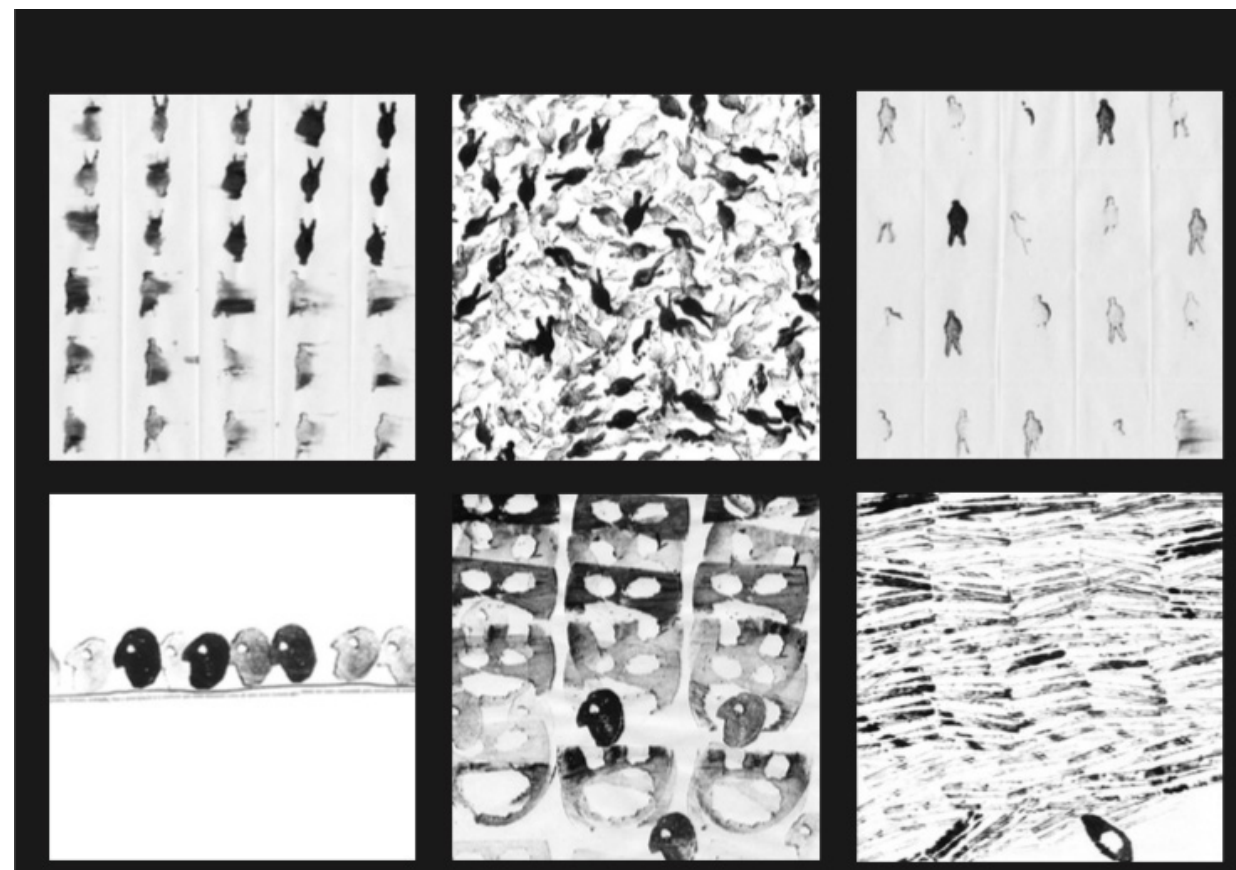
do autor.

Figura 15: Análise visual do livro "Un homme qui dort", Georges Perec (1967). In: TFG/FAU.USP Disforia Urbana e os Espectros do Anonimato na Metrópole Contemporânea (2012) de Cristina Myung Sun Gu. Fonte: Acervo do autor. 

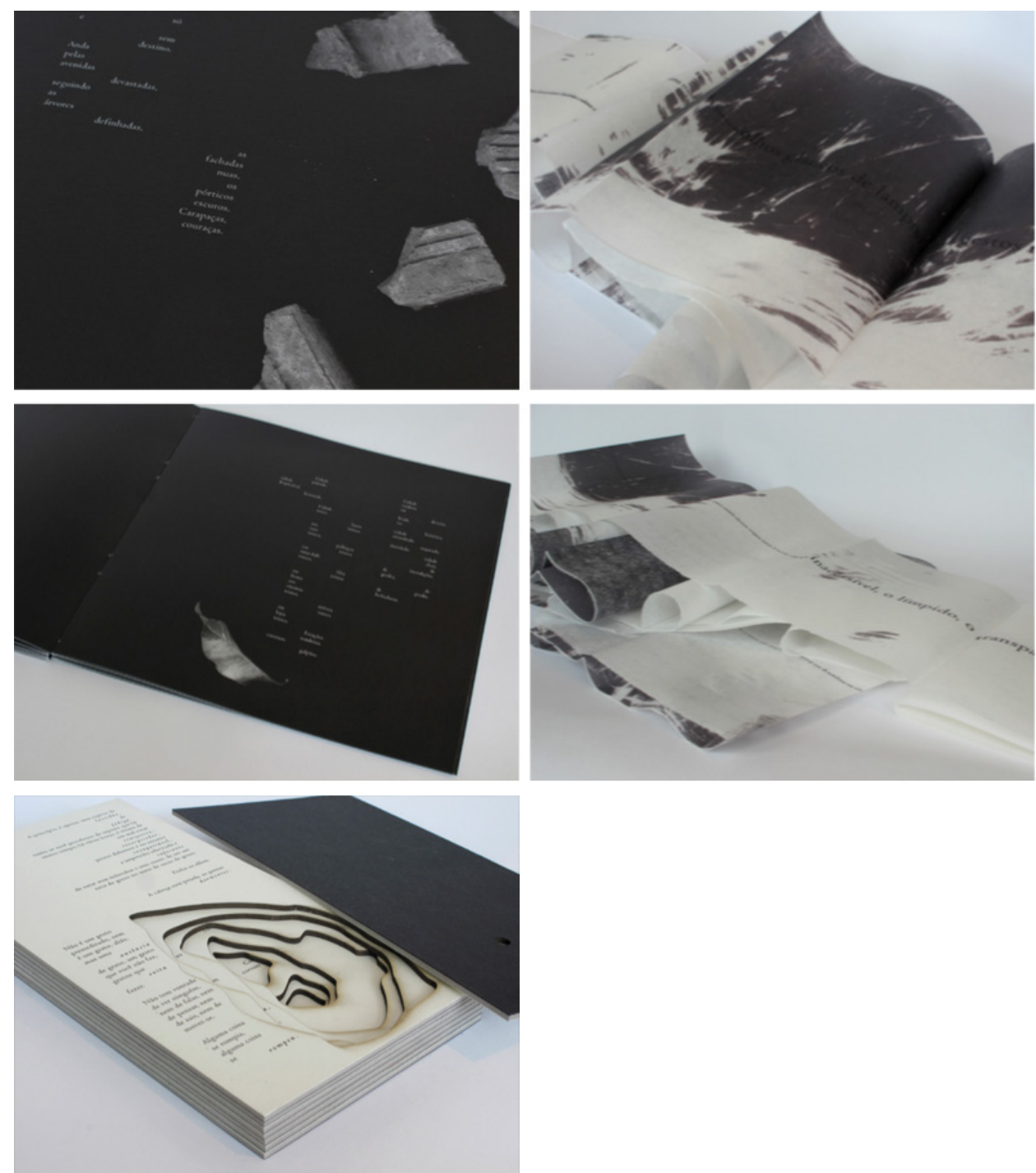

Figuras 16, 17 e 18: Volumes de transcriação de "Un homme qui dort", Georges Perec (1967). In: TFG/FAU.USP Disforia Urbana e os Espectros do Anonimato na Metrópole Contemporânea (2012) de Cristina Myung Sun Gu. Fonte: Acervo do autor. 
Figura 19: Páginas do Libreto do TFG/FAU.USP "Onde foi morar Bartô? Diálogos entre arquitetura e literatura" (2016) de Fernanda Schelp Lopes. Fonte: Acervo do autor.
Onde foi morar Bartô? Diálogos entre arquitetura e literatura (2016) de Fernanda Schelp Lopes é uma tradução intersemiótica de doze trechos selecionados do livro "Vermelho amargo" (2011) do escritor Bartolomeu Campos de Queirós, para um objeto composto por um libreto e doze modelos físicos - um para cada trecho da prosa-poética que caracteriza a escrita encantadora deste autor mineiro.

Por meio de esboços ou do desenho mais usual utilizado pelos arquitetos para projetar, buscou-se flagrar as espacialidades sugeridas (ou imaginadas) pelas narrativas literárias, registrando seus atributos de forma, luz, direção, percurso, ritmo, movimento, fechamento e abertura.

Com chapas delgadas de madeira balsa, foram projetadas e confeccionadas as maquetes a partir de uma modularidade de $5 \times 5 \times 2,5 \mathrm{~cm}$, dada a ortogonalidade dominante entre as planos que formam cada uma delas. Embora haja uma evidente autonomia entre cada um dos pares arquitetura/prosa-poética, projetou-se cada modelo como peças de um jogo de livre arranjo ou combinação. No libreto, os trechos literários selecionados são apresentados ao lado de fotografias das maquetes, enfatizando os parentescos e ressonâncias formais entre ambos, a partir de dois procedimentos: a exploração da dimensão visual da palavra escrita no espaço em branco do papel e, por fim, o registro fotográfico de uma vista - normalmente interna - da maquete iluminada artificialmente para explorar a geometria entre as luzes e sombras projetadas.

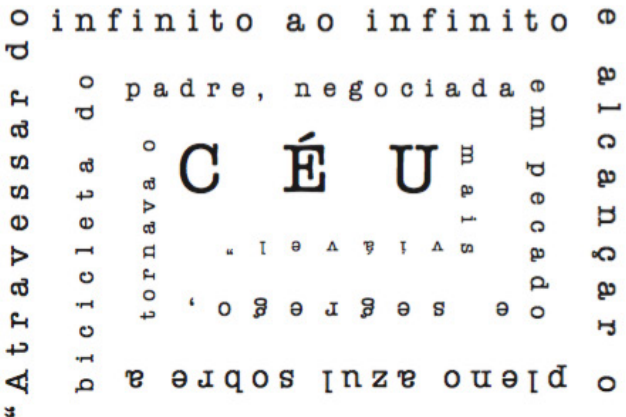

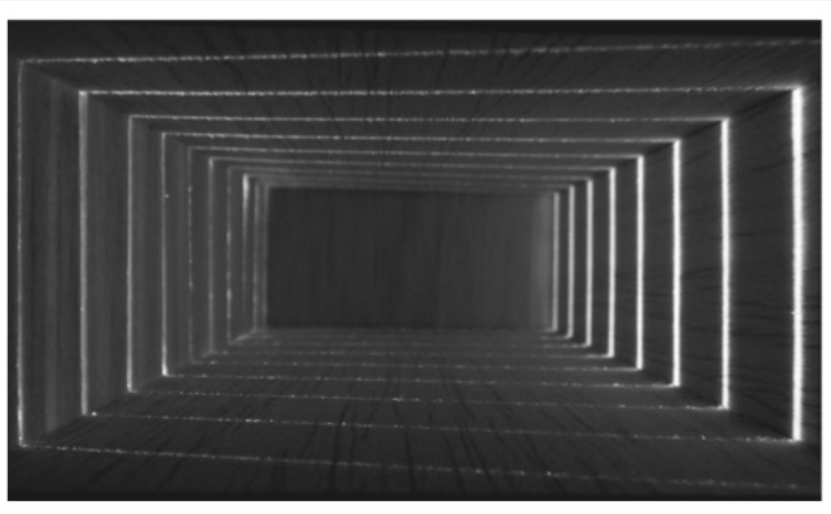



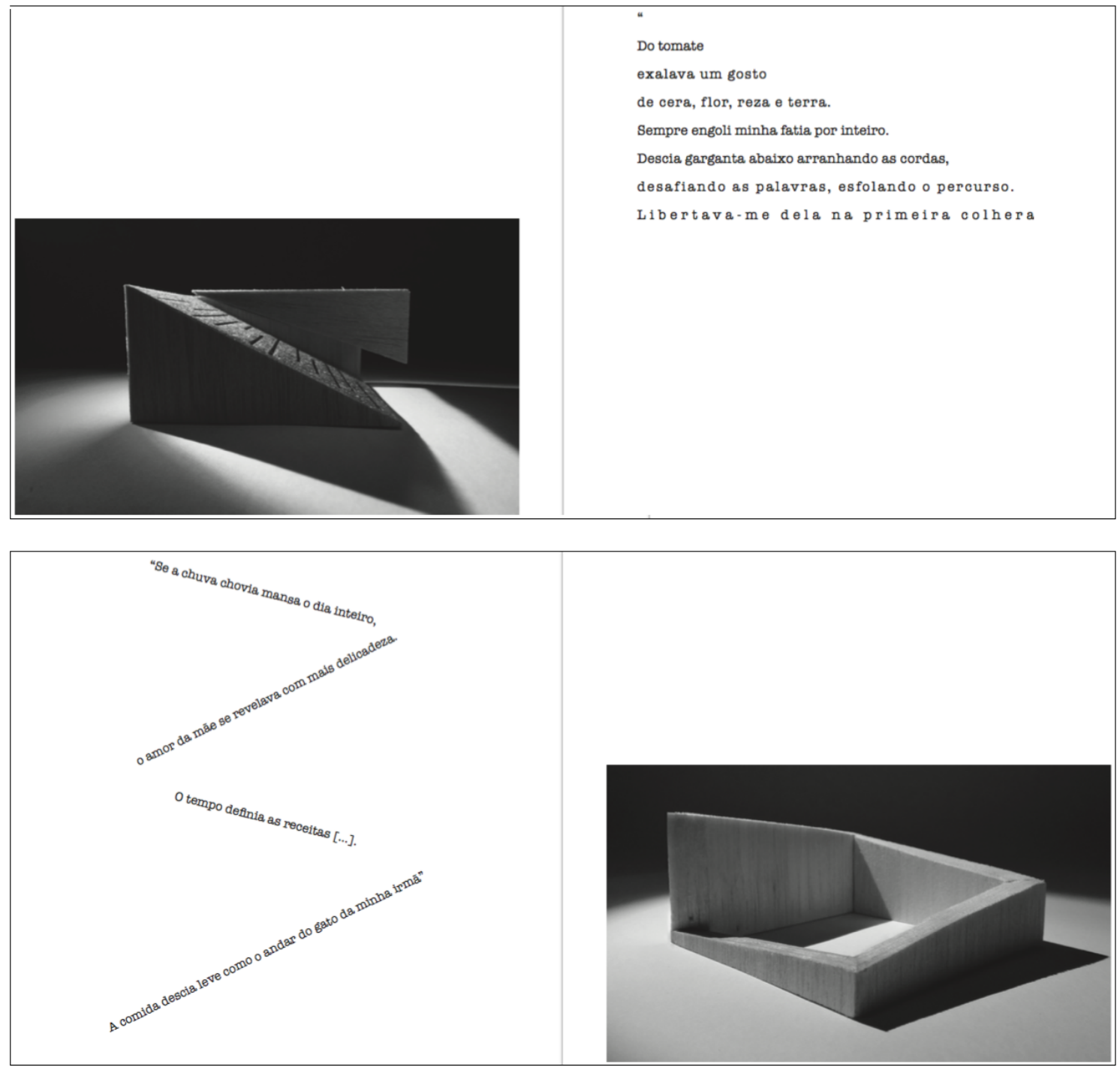

Figuras 20 e 21: Páginas do Libreto do TFG/FAU.USP "Onde foi morar Bartô? Diálogos entre arquitetura e literatura" (2016) de Fernanda Schelp Lopes. Fonte: Acervo do autor. 
Figura 22: Caixa (maquetes e libreto) do TFG/FAU.USP "Onde foi morar Bartô? Diálogos entre arquitetura e literatura" (2016) de Fernanda Schelp Lopes. Fonte: Acervo do autor.
Partindo de um diálogo entre arquitetura e literatura, como estratégia metodológica, o trabalho alcança um resultado de rara beleza sobre a poética na arquitetura. Ao cabo de tudo, é emocionante constatar que cada modelo também pode ser lido como um objeto autônomo da poesia que lhe deu à luz, pois o que ele é capaz de exprimir, por suas próprias qualidades e com a materialidade que Ihe constitui, não pode mais ser revertido ao verbal.

Podemos constatar aqui uma evidente manifestação de consciência icônica, de compreensão de quão complexos são os aspectos intangíveis do projeto ou, simplesmente, de atenção para a delicada matéria com que é feita a poesia em arquitetura.
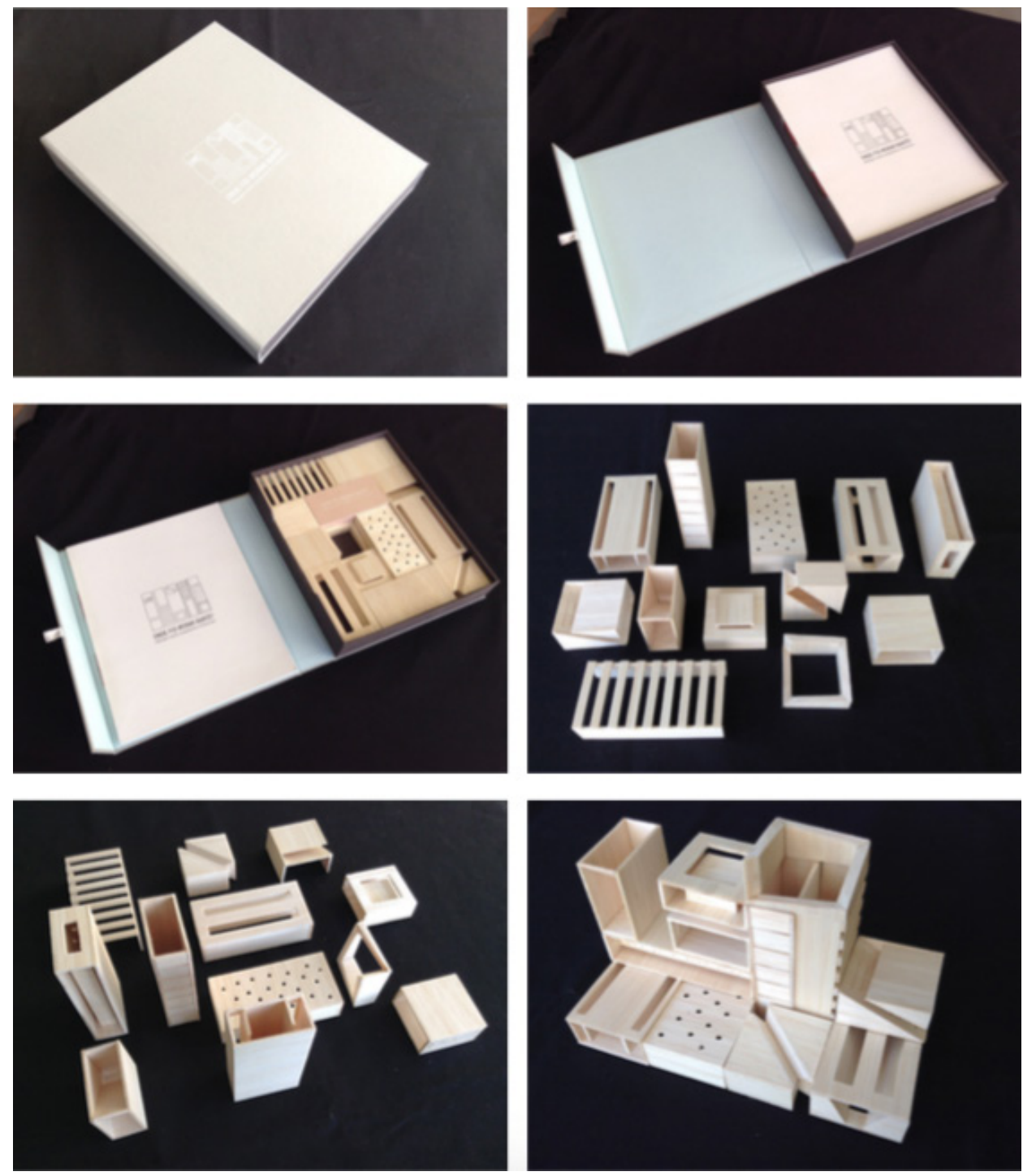
Som, Matéria, Espaço - "O Visconde partido ao meio" (2015) de Flora Belotti tem como ponto de partida o famoso romance de Italo Calvino, sub-título deste TFG, "Il visconte dimezzato" (1952) e, como objetivo, transpor a narrativa fabulosa, com personagens improváveis, rica em imagens inusitadas e de crescentes contrastes entre a delicadeza e a violência, para a materialidade de um espaço cênico, corpóreo e sonoro. Nesta fábula de Calvino, narrada por um sobrinho do visconde Medardo di Terralba, as ações dos personagens são entremeadas por momentos reflexivos que correspondem, respectivamente, a passagens multissensoriais, onde as descrições das imagens sugerem cheiros, cores, sons, sabores e texturas, e momentos "silenciosos" onde, por meio do pensamento, busca-se extrair sentidos dos fatos ocorridos.

A leitura do romance, em voz alta, no idioma italiano, explicitou os cantos nele contidos. A dimensão sonora das palavras da poesia em prosa tecida por Calvino, acabaram por conduzir os estudos da dimensão poética e definir uma chave interpretativa do texto. $\mathrm{E}$ as reflexões contidas nos livros "O som e o sentido" de José Miguel Wisnik e o "O ouvido pensante" de Murray Schafer, deram substância e fundamentação à esta análise, etapa essencial para a elaboração transcriativa e teatral de fragmentos eleitos do romance, expressa por corpos e espaço, danças e figurinos, sons, silêncios e palavras faladas, iluminação, movimento, duração e intervalos no pulsar do tempo.

À exceção do visconde, dividido em uma parte totalmente má e outra, totalmente boa, os demais personagens vivem em universos isolados que não se comunicam na narrativa. É reservado às andanças e aparições dos "meios viscondes", sempre separados, a conecção entre os personagens numa única história ou campo narrativo. Tal característica acabou por dirigir a criação de cada figurino, para cada personagem, como um microcosmo alegórico, tanto dos traços da personalidade de cada um, como dos signos da ambiência em que vivem. Assim, o palco, o espaço da representação é um vazio, onde os personagens estão imóveis, ao fundo, aguardando a sua vez de ocupálo, em uma sucessão de "solos" ou apresentações solitárias sob a voz do narrador do romance. O corpo é o suporte de um "manto-cenário", acionado pelos gestos deste ator ou bailarino, em consórcio com a leitura dramática de um hábil narrador de grande alcance vocal. 


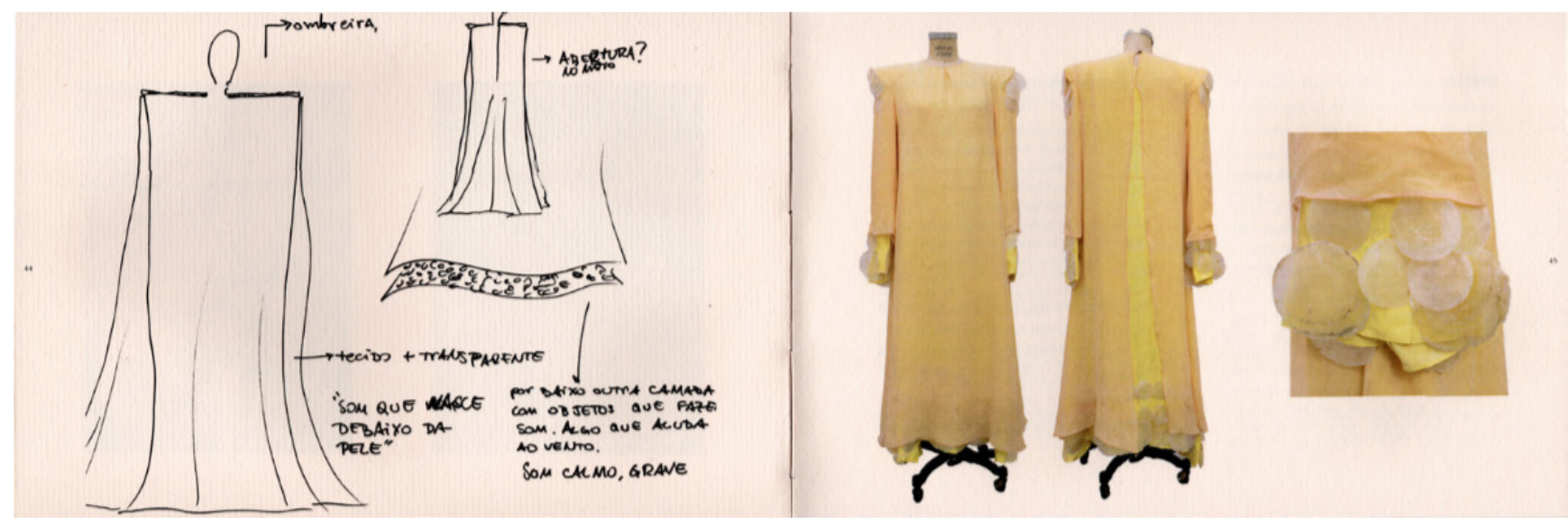

Figura 23: Figurino da personagem Velha Sebastiana. TFG/FAU. .USP Som, Matéria, Espaço - "O Visconde partido ao meio" (2015) de Flora Belotti. Fonte: Acervo do autor.
A velha Sebastiana amamentou todos os jovens da família Terralba, foi para cama com os mais velhos e fechou os olhos de todos os mortos, abandonou o castelo para viver com os leprosos em Prado Cogumelo. Maternal e sedutora, sábia e decidida, foi caracterizada, no trabalho, por uma veste monacal, composta por camadas de diferentes tecidos, um opaco, outro transparente, com suave coloração amarelo açafrão, e uma sonoridade pluvial advinda do bater e roçar das grandes madrepérolas presas na bordadura do barrado deste manto. 
Figura 24: Figurino da personagem Jovem camponesa Pamela. TFG/FAU.USP Som, Matéria, Espaço - "O Visconde partido ao meio" (2015) de Flora Belotti. Fonte: Acervo do autor.
A jovem camponesa Pamela é a mulher pela qual o(s) visconde(s) se apaixona(m). Tem a sua paz, sua inocência (ela fala com os animais) e sua alegria interrompidas pelo assédio do meio-visconde, sendo a primeira a perceber, que se tratavam de duas metades, ou de dois meios viscondes, descobrindo a existência da metade que se supunha perdida, após o tiro de canhão que vitimara a nobre figura. Sua vestimenta, então, foi concebida para produzir dois tipos de sons: de guizos e chocalhos, marcando a dualidade dos dois amores que a vitimam. A descrição de Pamela é feita por fraseado rimado, rico em aliterações e sonoridades melódicas. Complementam a sua capa, provida de um capuz, um bordado de penas, para representar seu lado silvestre, na companhia dos animais, e outro bordado de "meios presentes" recebidos do visconde: meias margaridas, meias umbelífeas, meios morcegos, meios dentes de leão, etc. Seu lamento contínuo, em função de um destino que renega, é similar ao balido de uma cabra: Ai me di me, ai me me di me, ai me me me di me...
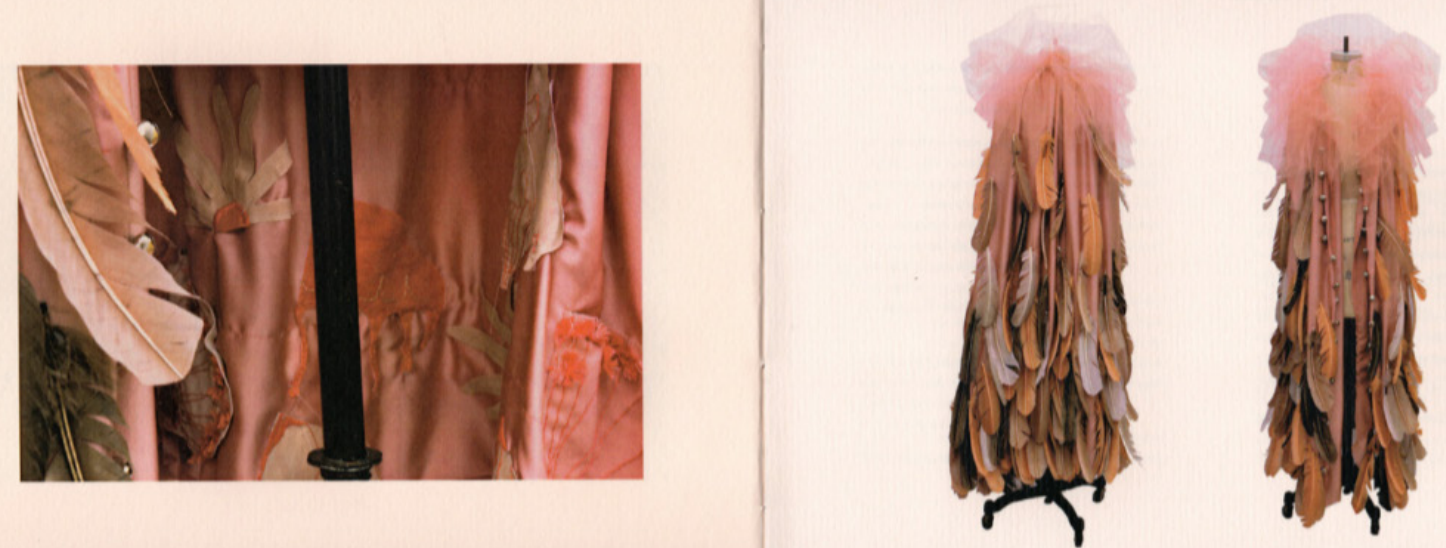


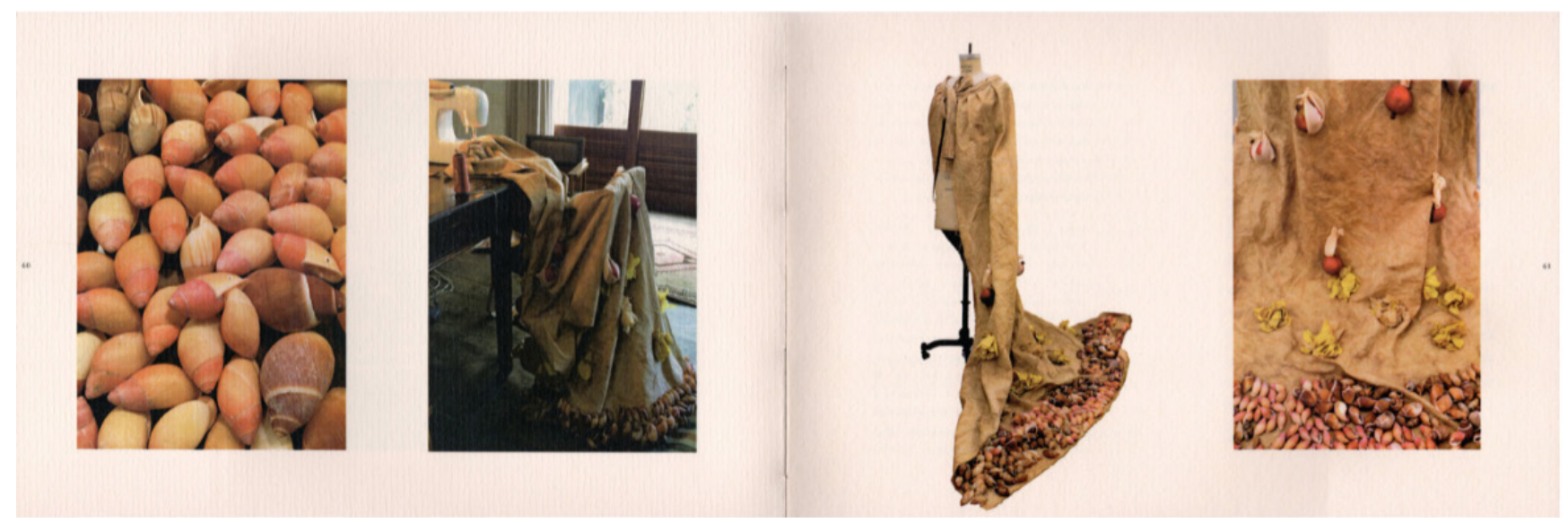

Figura 25: Figurino do personagem Dr. Trelawney. TFG/FAU. .USP Som, Matéria, Espaço - "O Visconde partido ao meio" (2015) de Flora Belotti. Fonte: Acervo do autor.
O médico Dr. Trelawney abomina doentes, tem aversão a sangue e persegue fogosfátuos. Seu manto é feito de uma lona rústica, quase uma carapaça terrosa, da cor e do aroma do café, que contrasta com a leveza ligeira dos gestos dos seus braços, onde são presas as mensagens deixadas pelo visconde, sempre como sinais a serem decifrados: romãs ensacadas, girassóis e escargots. Tais apliques produzem um som levemente agudo que alude ao tilintar dos frascos de vidro que o doutor manipula. 
Figura 26: Aparato Cênico do personagem O mestre carpinteiro Pedroprego. TFG/FAU.USP Som, Matéria, Espaço - "O Visconde partido ao meio" (2015) de Flora Belotti. Fonte: Acervo do autor.
O mestre carpinteiro Pedroprego, por falta de outras encomendas e obediente às ordens do tirânico meio-visconde, aperfeiçou-se na arte de construir forcas e instrumentos de tortura, todos muito engenhosos, verdadeiras obras primas da carpintaria e da mecânica. Tal personagem foi representado por um boneco de madeira preso a um requadro móvel repleto de pedaços de corpos esquartejados suspensos por cordas e roldanas, conformando um sinistro marionete onde o personagem principal e os fragmentos de corpos que gravitam em seu entorno, participam de um tenebroso e coordenado movimento maquínico.
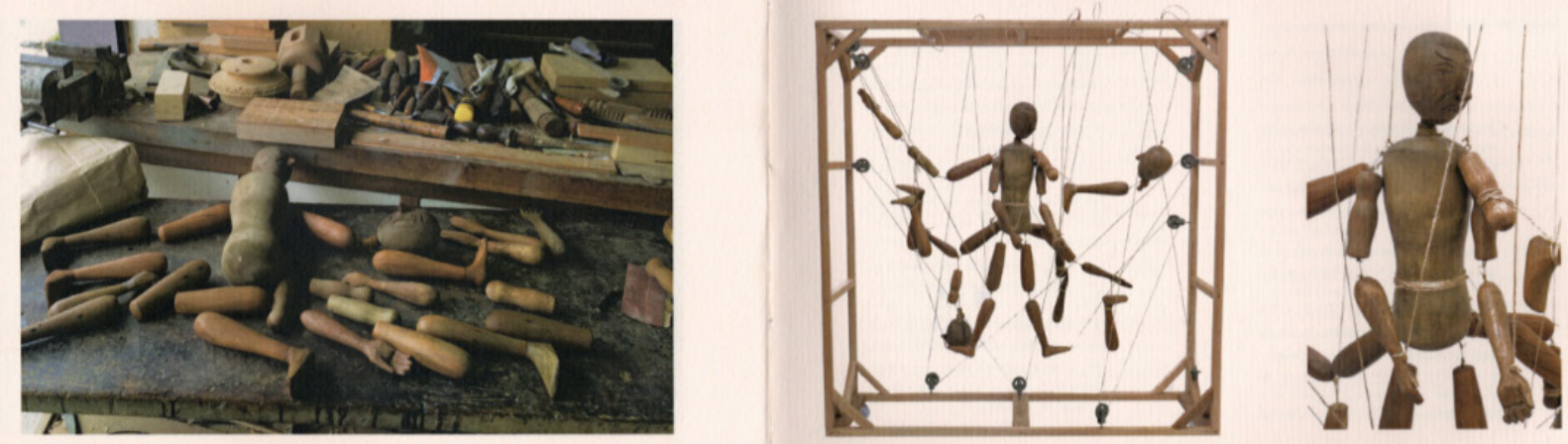


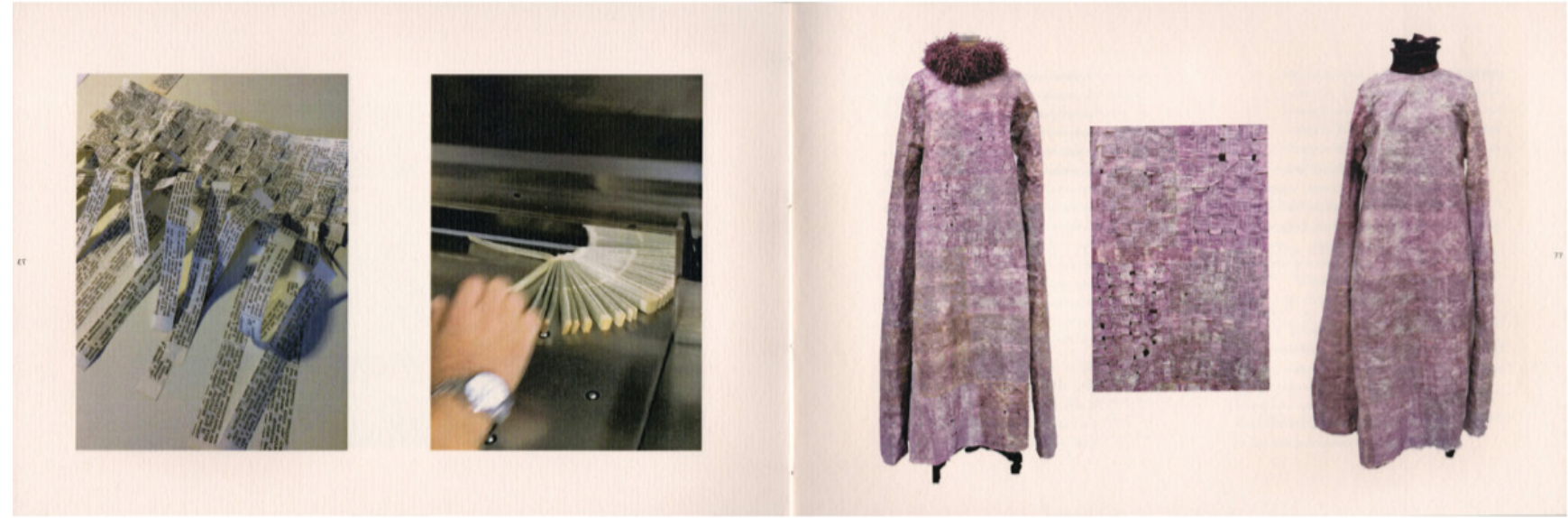

Figura 27: Figurino do personagem Ezequiel. TFG/FAU.USP Som, Matéria, Espaço - "O Visconde partido ao meio" (2015) de Flora Belotti. Fonte: Acervo do autor.
"Peste e carestia" brada Ezequiel, o líder dos Huguenotes, comunidade religiosa isolada, expulsa da França, dedicada ao trabalho, à castidade e à mútua vigia em um ambiente de proibições e de severas condenações a atos sacrílegos. A rigidez dominante levou ao desenho de vestimentas que restringem os movimentos dos corpos para que ela não se desfaça, dada a fragilidade do material com que foi tecida: um trançada de finas tiras cortadas, com guilhotina, de edições populares e tradicionais da Bíblia. A ambiguidade entre as rigorosas determinações religiosas e a possibilidade imanente de desobedece-las foi representada pelo desenho de uma roupa solene que cobre todo o corpo e cujas mangas compridas tocam o solo, presas a sacos de pedras que precisam ser levantados para o personagem se mover, quando são erguidos e soltos ao chão novamente, produzindo o som de um baque seco a cadenciar o grito "Peste e carestia". 
Figura 28: Figurino dos quatro personagens leprosos. TFG/FAU. .USP Som, Matéria, Espaço - "O Visconde partido ao meio" (2015) de Flora Belotti. Fonte: Acervo do autor.
Os leprosos, igualmente isolados, são, ao contrário dos huguenotes, licenciosos, libertinos e festivos. Em estado de embriaguez contínua, pelo consumo do vinho que produzem, apreciam a música e se ocupam de tocar instrumentos por eles inventados. É o culto das sensações e da sensualidade, do amálgama do corpo com o mundo material, intermediado pelo tato e pela pele doentia, escamosa, arroxeada e pútrida. A doença os une, aprisionando-os a um destino comum, a uma vida de isolamento, privações e preconceitos. Suas roupas, então, foram desenhadas para serem leves, feitas de diversos tecidos (seda, linho, algodão), para oferecer liberdade de movimentos e exibir os corpos. Tingidas pela cor do vinho, concolor a cor da pele doente, as vestimentas formam quatro combinações diferentes, para quatro leprosos, representando um trupe festiva e turbulenta, em movimentos solidários, unidos por cordas elásticas, como uma dança desordenadamente embriagada. Cada um dos quatro personagens produzirá sons com instrumentos próprios, uns inventados, outros não, cantando o seguinte soneto em falsete: "il pucino senza macchia, va per more e si macchió".

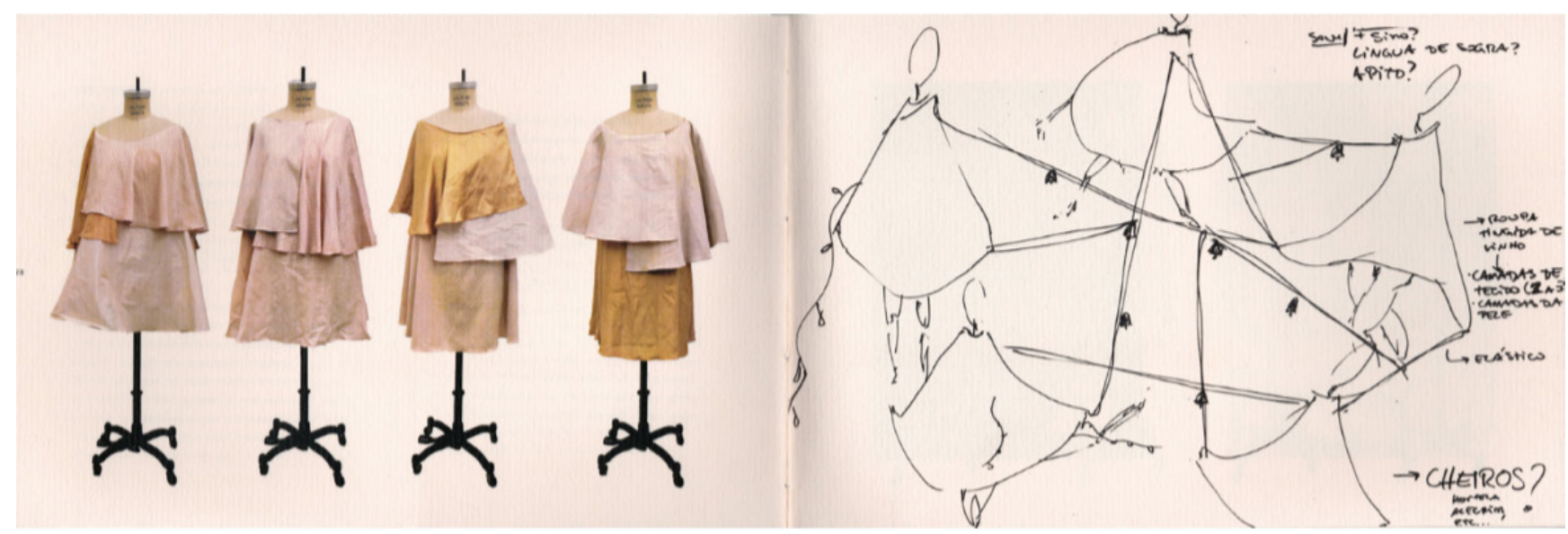


Figura 29: Figurino do personagem Visconde Medardo di Terralba. TFG/FAU.USP Som, Matéria, Espaço - "O Visconde partido ao meio" (2015) de Flora Belotti. Fonte: Acervo do autor.

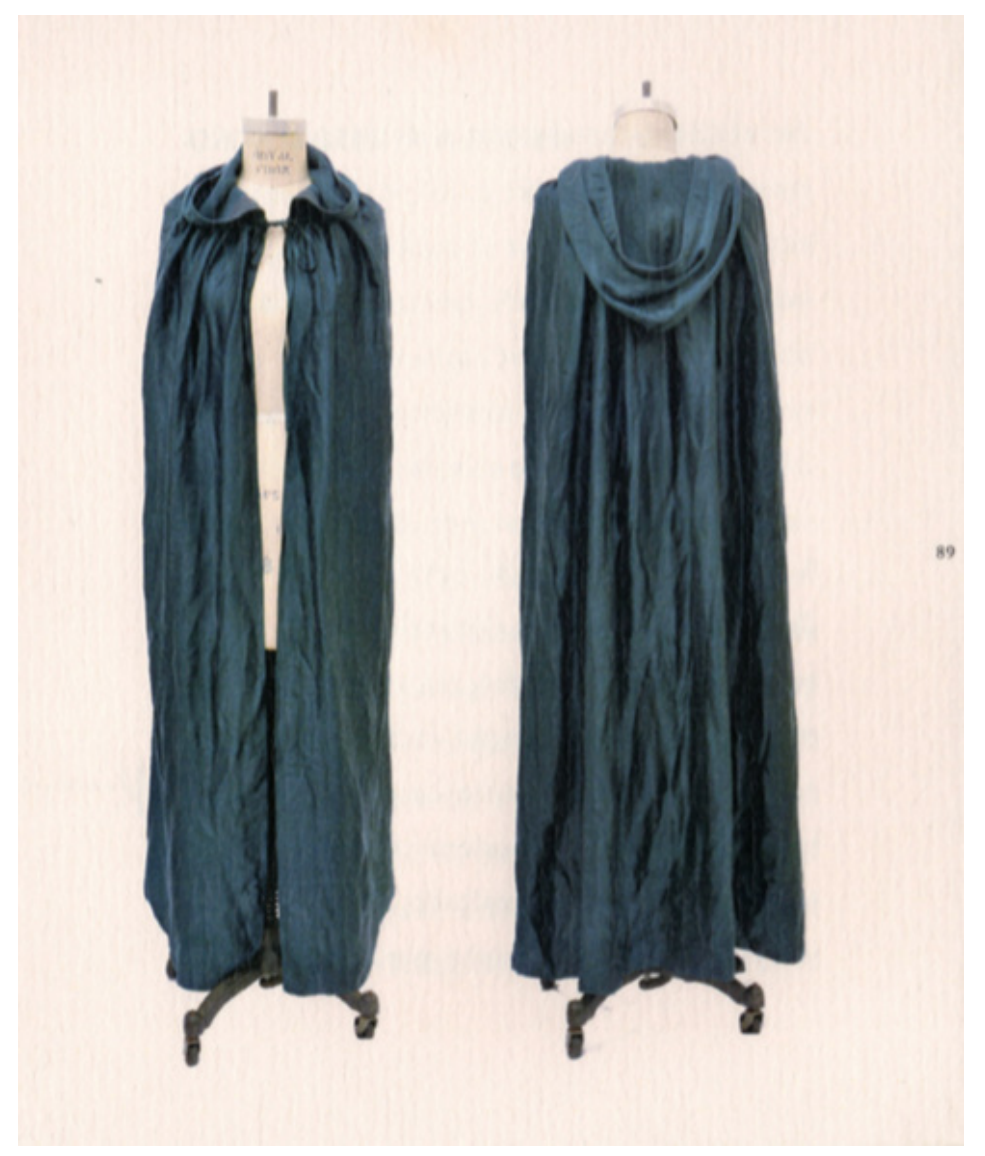

O visconde Medardo di Terralba é uma vítima terrivelmente mutilada da guerra contra os turcos. Reconstituído por cirurgiões, um manto cobre o que restou do seu corpo e, principalmente, esconde a parte que lhe falta, simétrica a primeira e que se supunha perdida, mas que, após um largo lapso de tempo, retorna a Terralba. Um duelo, ao final do romance, entre as duas metades simétricas, na fisicalidade dos corpos e no antagonismo ético de duas moralidades opostas, uma bondosa, outra mesquinha, sela o destino do visconde. Ambas as metades, feridas de morte, são reconstituídas, cirurgicamente, em só corpo: um visconde inteiro, "nem mau nem bom", uma mistura de ambos, "aparentemente igual ao que era antes de se partir ao meio". $O$ visconde tem duas entradas em cena, representando por duas bailarinas gêmeas, idênticas, vestidas com longos mantos de seda de um azul escuro, cujos caimentos acompanham os passos, os giros e saltos de um balé clássico. O par de dançarinas desenvolve movimentos intercalados de ruptura e união. 

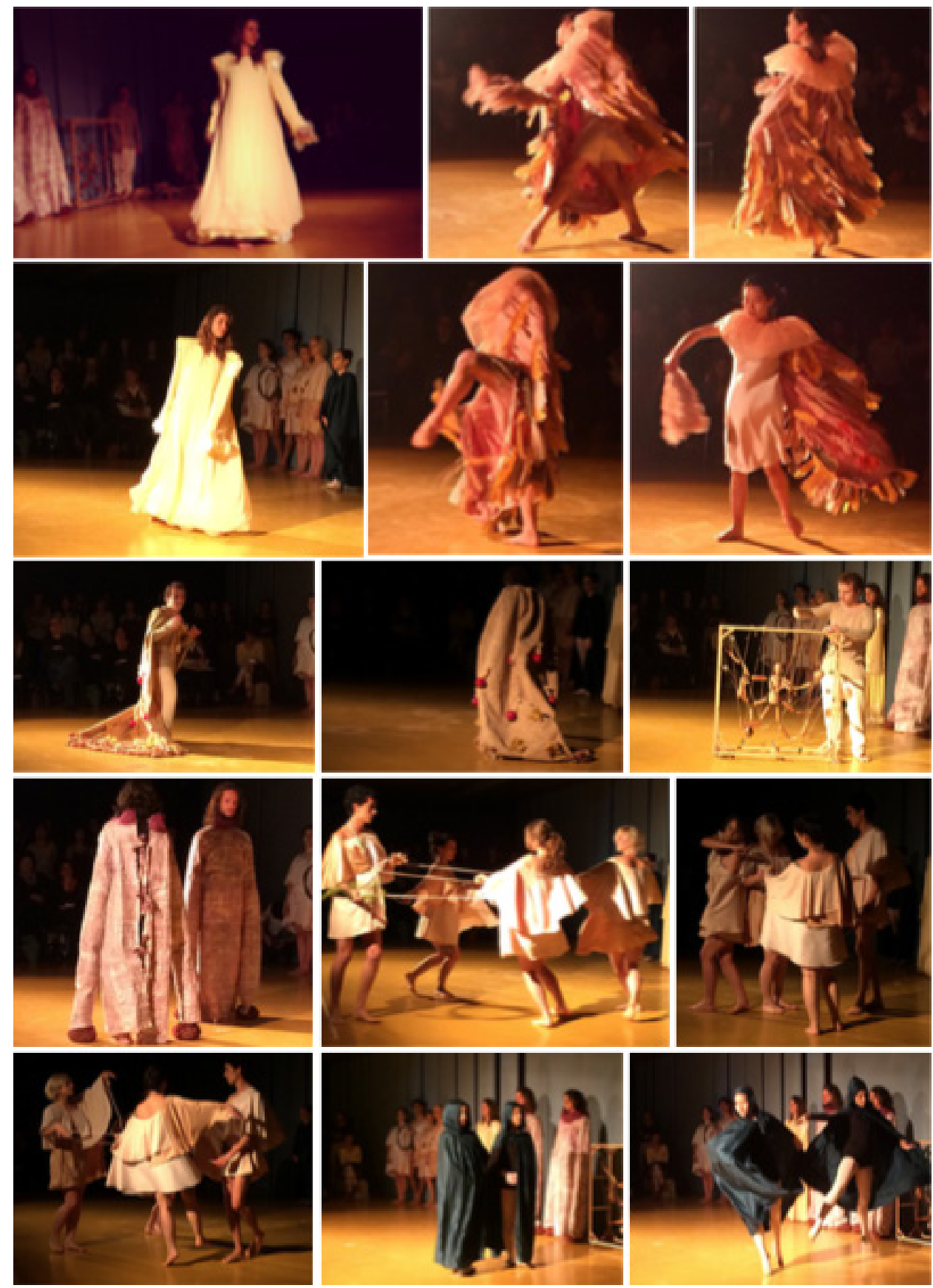

Figura 30: Cenas da encenação final. TFG/FAU.USP Som, Matéria, Espaço - "O Visconde partido ao meio" (2015) de Flora Belotti. Fonte: Acervo do autor.
Estes personagens encerram um conjunto de figurinos-cenários concebidos para dar voz, sons, existência espacial e material à fina prosa de Calvino.

Uma outra abordagem para realizar um trabalho de transcriação é a que privilegia a dimensão metafórica, semântica e simbólica do texto literário. Este é o caso deste TFG. 
Figura 31: Capas de diversas edições (várias datas) do livro "Metamorfose" (1912) de Franz Kafka. Fonte: Acervo do autor.
INSEKTABSCHEUMETAPHER de Bianca Lucchesi (2015) - cujo título é um neologismo criado a partir das palavras insekt (inseto), abscheu (aversão, repugnância) e metapher (metáfora) - realizado a partir do romance "Metamorfose" de Franz Kafka. Obra escrita em 1912, nos antecedentes da Primeira Guerra Mundial, teve a sua primeira edição, em 1916, com uma capa ilustrada por uma gravura que não representa o inseto no qual o protagonista Gregor Samsa teria se metamorfoseado. Outras edições, nas mais variadas línguas, tiveram capas com ilustrações de insetos, como barata ou besouro. No texto original, em alemão, não se define qual é este inseto - o que não é observado em algumas traduções interlinguísticas.
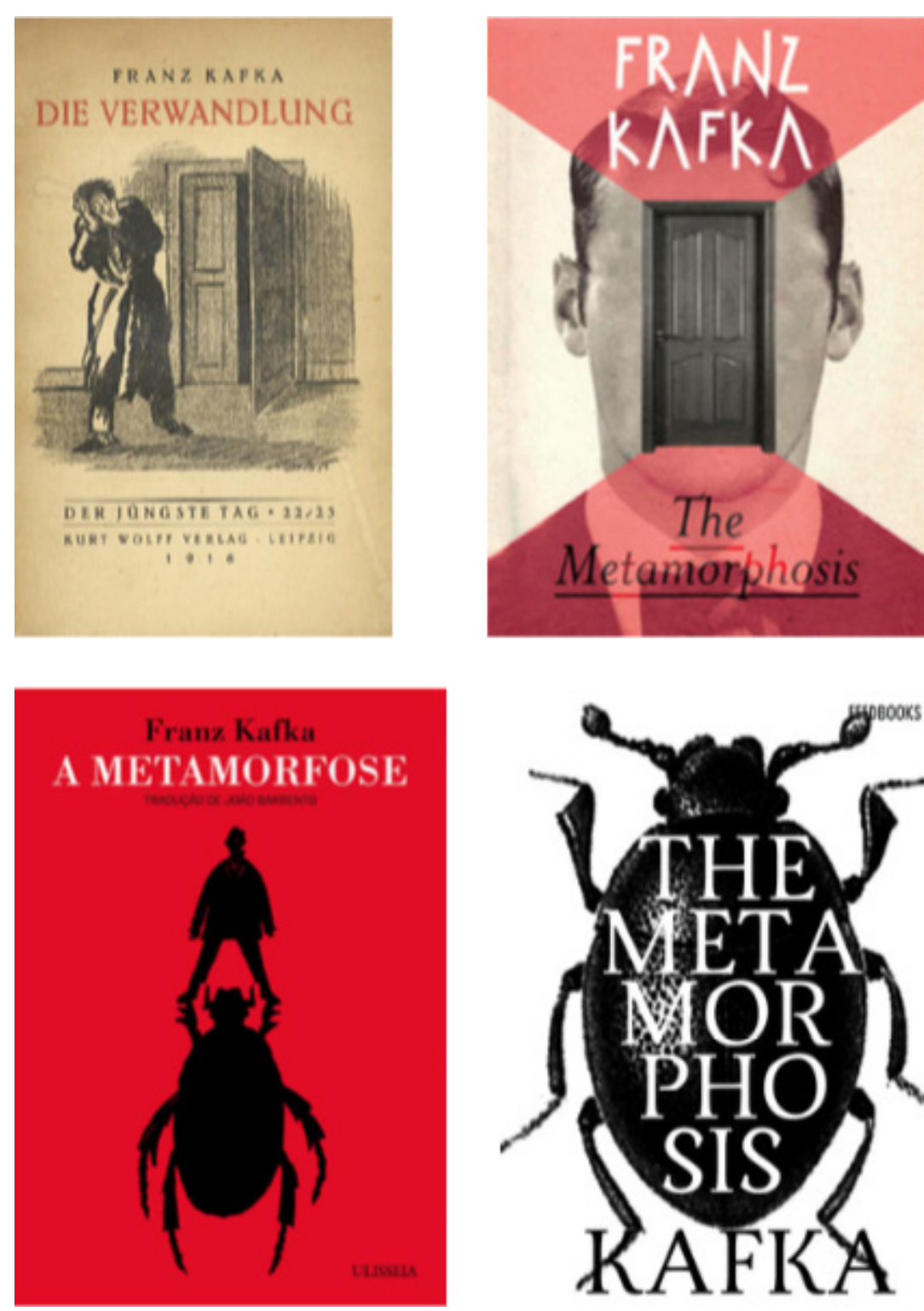

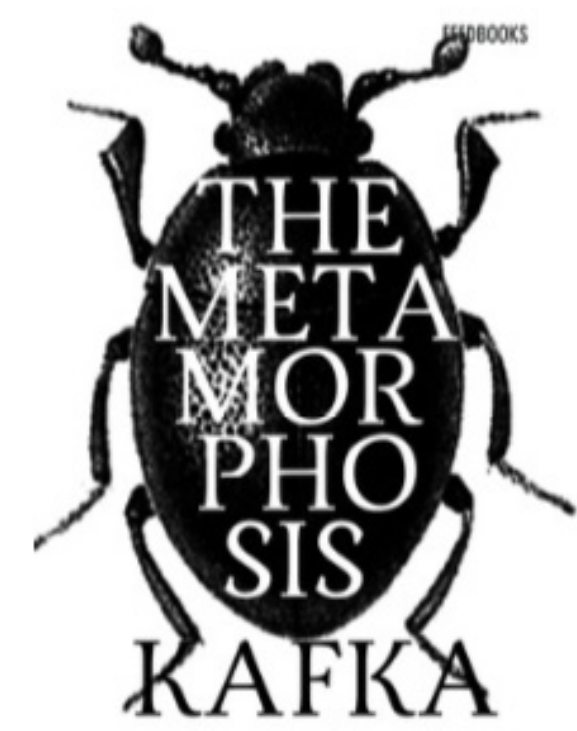

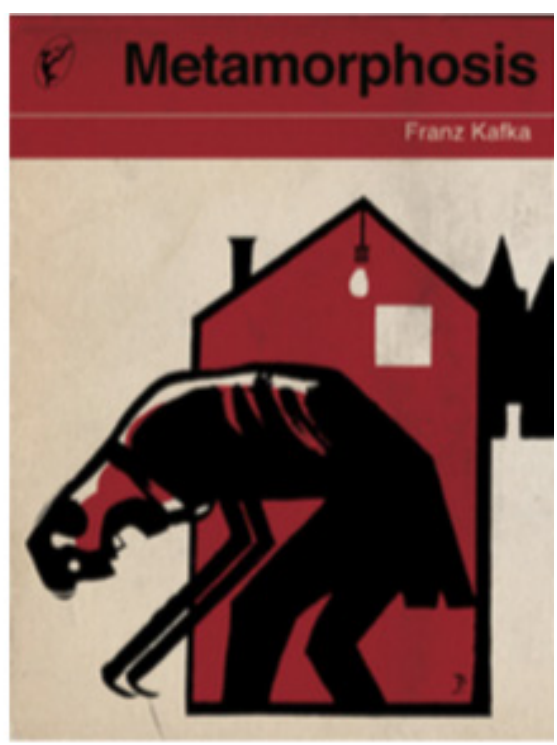

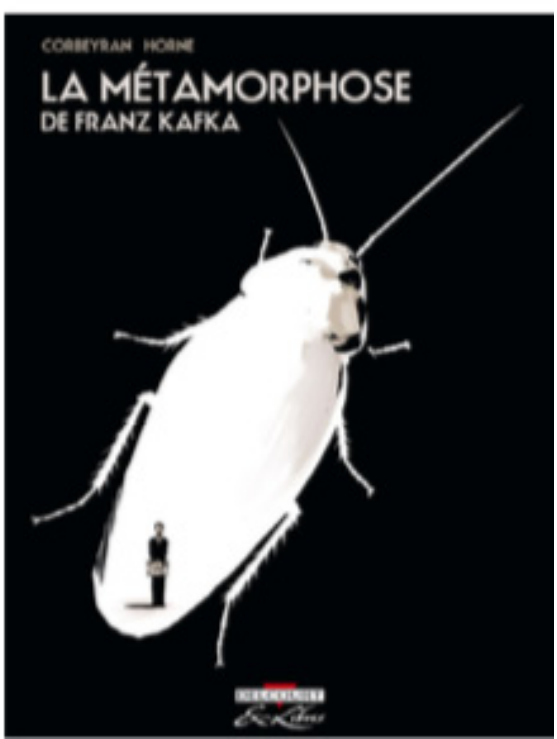



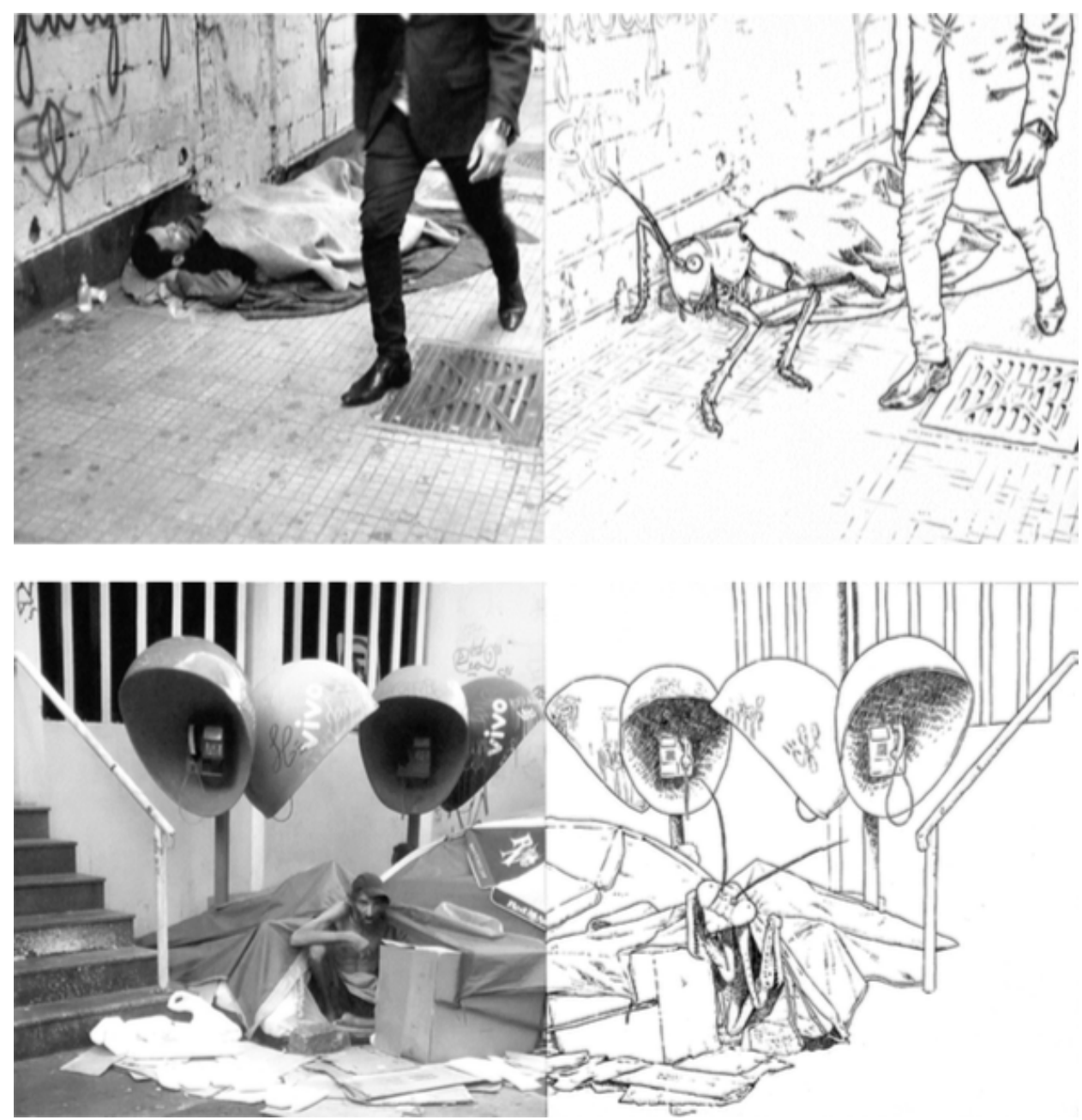

Figura 32: Páginas do TFG/FAU. USP "INSEKTABSCHEUMETAPHER" (2015) de Bianca Lucchesi. Fonte: Acervo do autor.
A interpretação do célebre romance kafkaniano atribuiu à metamorfose do homem em um inseto, uma metáfora do isolamento social e psíquico do personagem, caracterizado pela profunda inapetência em lidar com a ordem do mundo, com seus valores e costumes e com as pessoas com as quais o personagem convive (os diferentes membros da família, os colegas de trabalho, etc), portanto, da ruptura com o mundo ou com a sociabilidade que ele impõe por meio de um atendimento a toda uma sorte de modelos comportamentais. Tal interpretação transcende o tempo histórico daquele contexto e leva à generalização desta condição humana - chamada, no trabalho, de "estado inseto" da vida - para poder ser encontrada na realidade atual da metrópole paulistana. Ou seja, para a sublinhar a permanência desta poderosa metáfora em outros tempos e espaços, procurou-se identificar e representar as manifestações deste "estado inseto" de vida em São Paulo, descendo ao inferno das nossas desigualdades e injustiças sociais, vasculhando as várias formas de estigmatização, preconceito e segregação presentes na nossa sociedade. Aliando o registro fotográfico e o desenho de ilustração a fragmentos do texto de Kafka, concebeu-se e produziu-se um livro objeto, de forte impacto, seja pela expressão literal das metáforas em termos visuais (paramorfismos, diria Décio Pignatari), seja pela crueza banal dos retratos de personagens reais. 
Por fim, uma última estratégia de trabalho de transposição da literatura (prosa, poesia e canção) para o campo das artes gráficas - São São Paulo de Luisa Amoroso Guardado (2012) - relaciona-se com o tema e as motivações do grupo de pesquisa que coordeno ("Representação dos lugares na cultura brasileira"), na medida em que procura abordar a cidade de forma indireta, ou melhor, por meio dos retratos que dela fizeram seus mais destacados artistas. Trata-se de uma aproximação dos lugares da cidade mediada pela arte, ou seja, pelo discurso poético. Escolhese um lugar como tema e seleciona-se obras de arte sobre ele para investigar a instrução que tais obras realizam para o nosso conhecimento dos lugares ou para a cultura das cidades. Procura-se enriquecer os sentidos da cidade, visitando as suas representações no campo da arte, privilegiando, portanto, a dimensão poética de tais discursos e, finalmente, promovendo o patrimônio cultural sobre nossas cidades e seus lugares.

Este TFG enfrenta, cuidadosamente, a história da cidade de São Paulo, tema recorrente na FAU-USP, para situar os quatro retratistas que oferecerão substância poética para iluminar o sentido da cidade: Mário de Andrade, Antônio de Alcântara Machado, Adoniran Barbosa e Itamar Assumpção, cronologicamente apresentados. Foram produzidos quatro libretos, um para cada autor, dispostos em uma caixa do tamanho de um Long Play que também acondiciona o trabalho de pesquisa, de estudos teóricos e a monografia resultante. A ilustração (desenho, colagem, fotografia, montagem) é a linguagem dominante nas traduções realizadas, orientadas para destacar a cidade presente no eu-lírico que lhe dá vida e imagem.

"Paulicéia Desvairada", de Mário de Andrade, celebra o canto lírico, de amor a São Paulo, de um trovador moderno, um evocado e sentimental Arlequim com o seu típico traje multicor, comovido com a cidade pulsante, imerso na diversidade do mundo urbano, visto como um mosaico de imagens e sentimentos. Um deslocado tupi tangendo um alaúde na Paulicea da grande boca de mil dentes. 

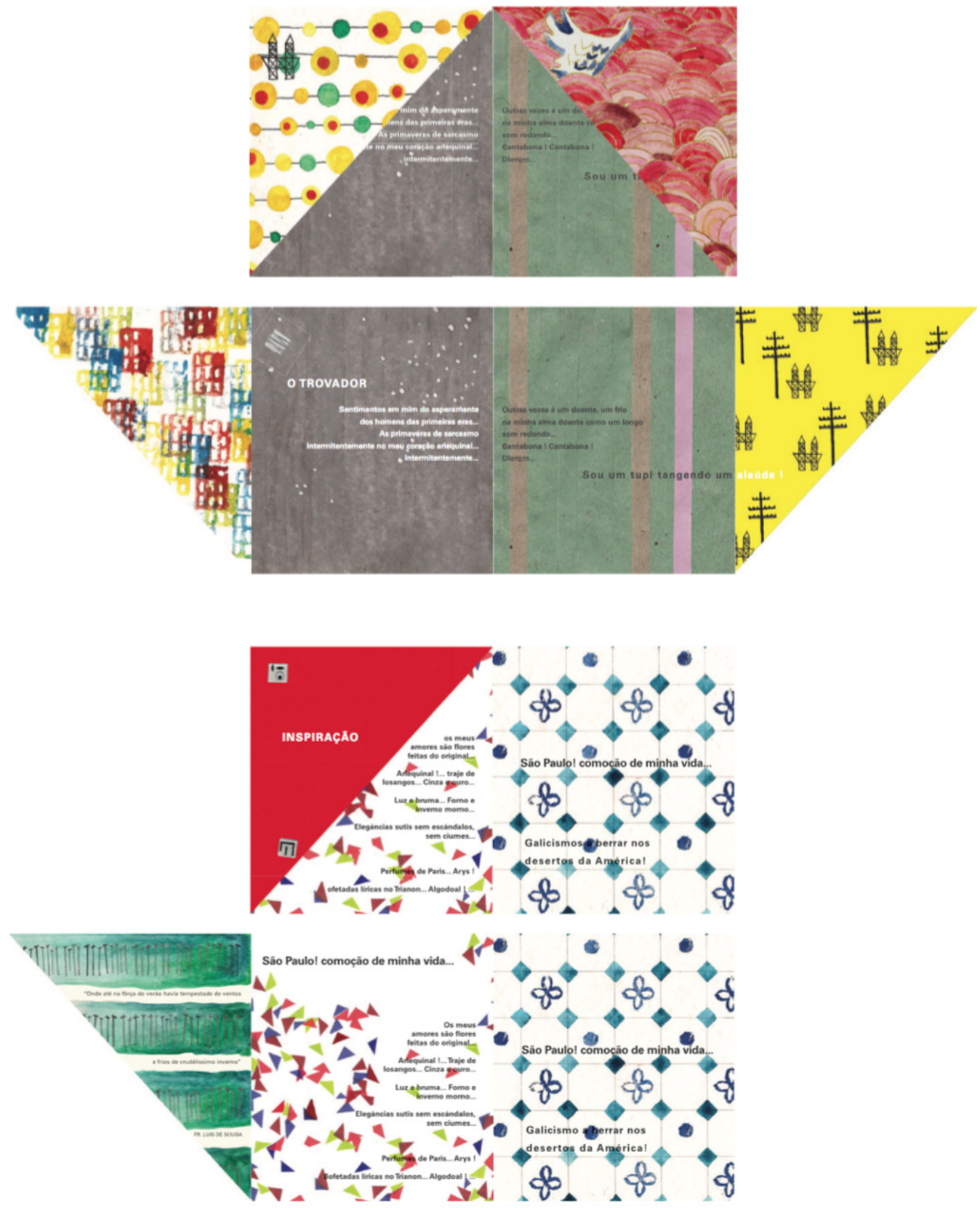

Figuras 33 e 34: Libreto "Mario de Andrade". TFG/FAU.USP São São Paulo (2012) de Luisa Amoroso Guardado. Fonte: Acervo do autor. 

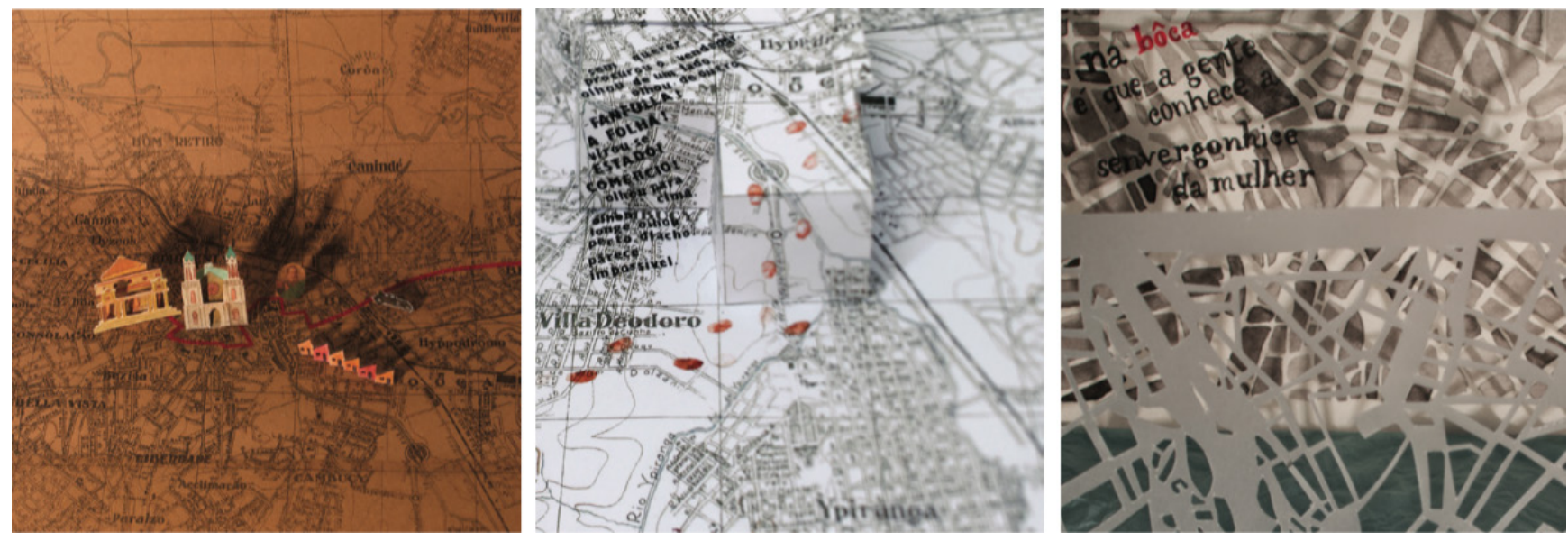

Figura 35: Libreto "Antônio de Alcântara Machado". TFG/FAU. .USP São São Paulo (2012) de Luisa Amoroso Guardado. Fonte: Acervo do autor.
De "Laranja da China", de Alcântara Machado, foram extraídos os contos "O Patriota Washington", "O Filósofo Platão"," O Aventureiro Ulisses" e o"Tímido José", retratos cômicos de personagens deambulantes pela cidade que, a despeito dos títulos heroicos dados a cada uma das narrativas, encerram o duro cotidiano de homens comuns, nos primórdios da metrópole paulista. 
Figura 36: Libreto "Adoniran Barbosa". TFG/FAU.USP São São Paulo (2012) de Luisa Amoroso Guardado. Fonte: Acervo do autor.
Adoniran Barbosa inventou uma dicção bem humorada, um sotaque para um tipo popular do paulista, íntimo dos lugares tradicionais de São Paulo, tão reconhecíveis, quanto banais. Um narrador que oscila entre uma contida euforia, uma pontinha de orgulho do seu lugar na cidade, e uma frequente, mas resignada melancolia, própria das agruras da vida de poucos recursos nos bairros pobres, operários ou populares.
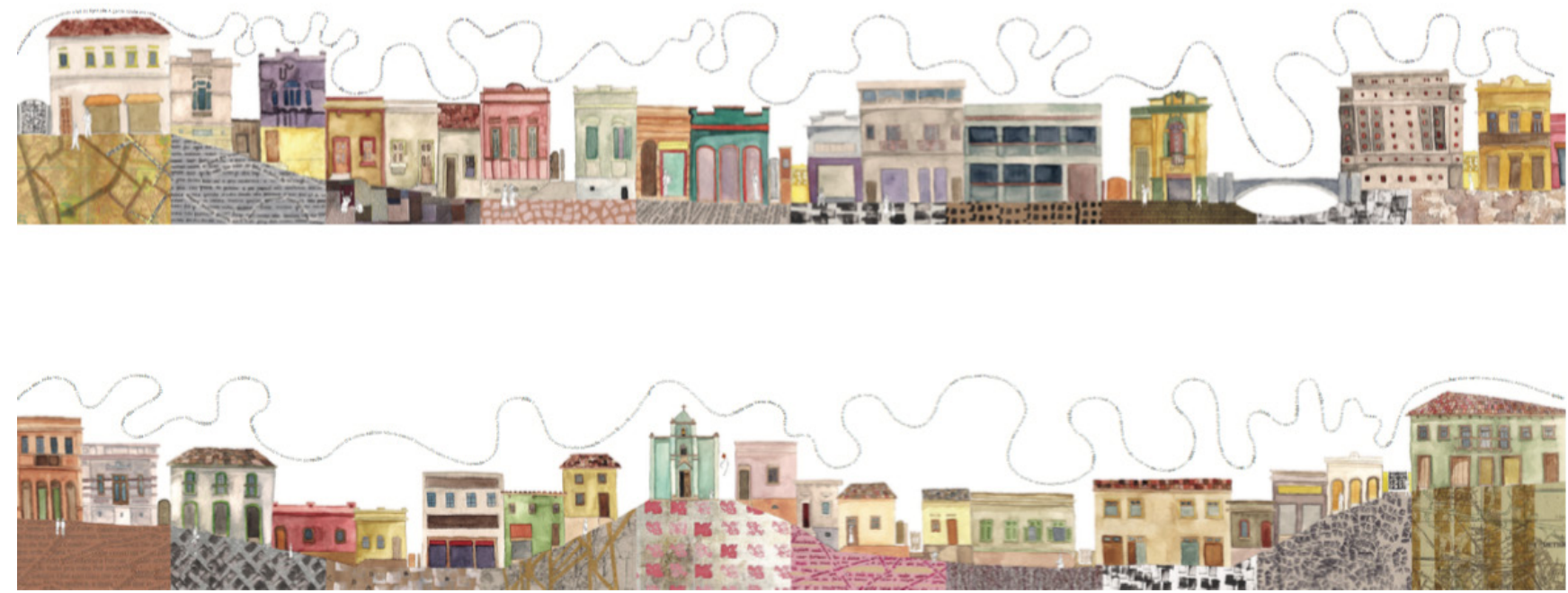

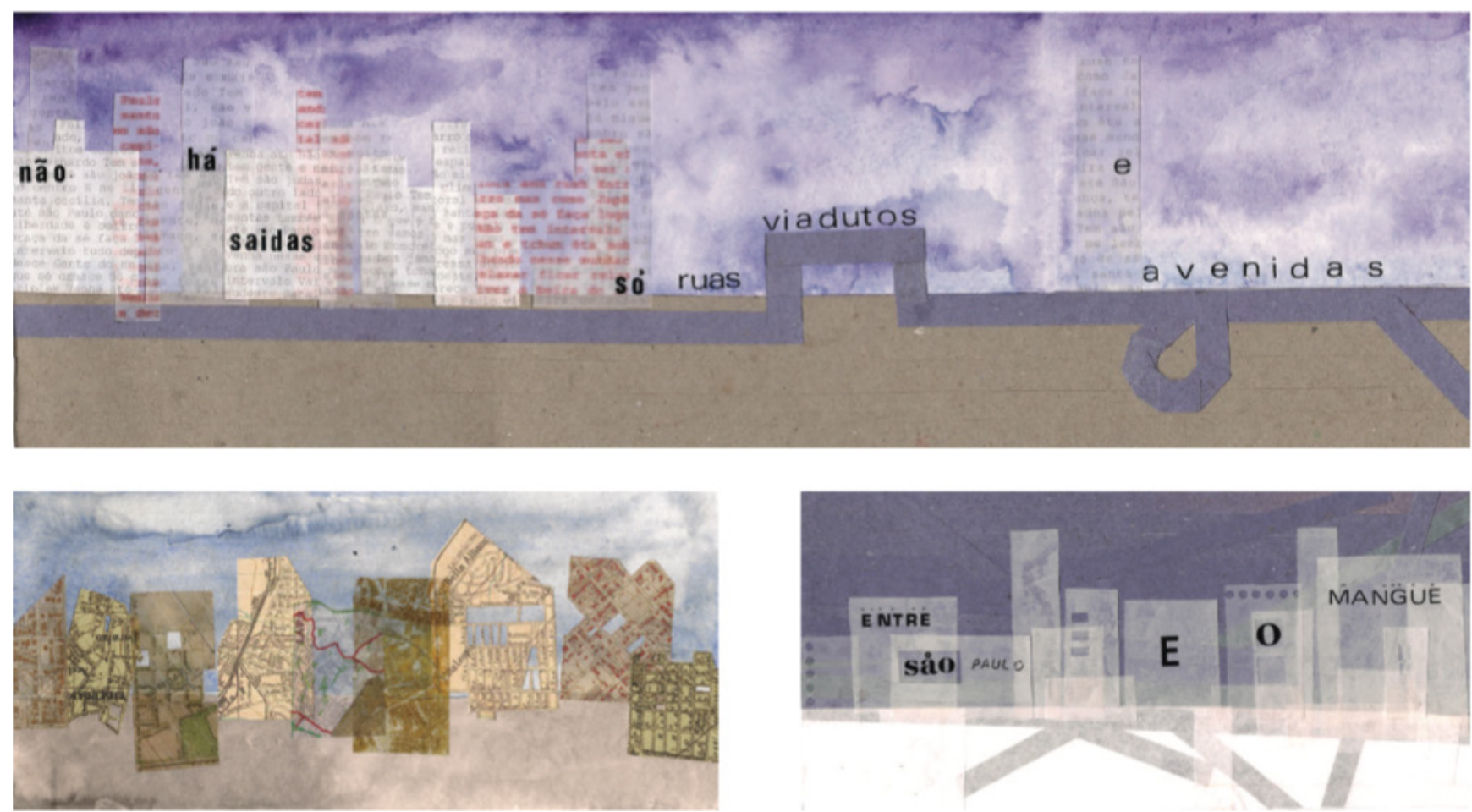

Figura 37: Libreto "Itamar Assumpção". TFG/FAU.USP São São Paulo (2012) de Luisa Amoroso Guardado. Fonte: Acervo do autor.
Bom humor que também pontifica, por meio dos trocadilhos e das ambiguidades presentes nas canções de Itamar Assumpção: "Venha até São Paulo ver o que é bom pra tosse. O lirismo ácido, sarcástico, crítico e reflexivo de um trovador, como o Mário de Andrade, identificado com a inquietação experimentalista dos movimentos de vanguarda e, profundamente, atento à imensa tradição cultural da música popular brasileira.

São Paulo, ao contrário de outras cidades brasileiras, não é retratada por valores ou virtudes em si mesmos, mas, eles comparecem filtrados e entremeados por histórias de vida, com personagens reais ou imaginários posicionados à frente da narrativa e que, ao contarem seus feitos ou testemunhos, deixam transparecer as qualidades ou defeitos característicos da identidade desta cidade. Os retratos da cidade de São Paulo na cultura brasileira, como podemos ver nos quatro autores do TFG de Luisa Amoroso, são a sua gente. 
O conjunto de trabalhos - TFGs - apresentados forma uma constelação de projetos, com os mais diversos suportes materias e linguagens, orientados pela análise de obras literárias, com evidente foco na função poética da linguagem verbal. Os trabalhos têm, em comum, a forma de abordagem da elaboração projetual, principiada pela atividade tradutória dos aspectos poéticos da peça literária analisada, tradução esta que exige um trabalho de (trans)criação dos aspectos e atributos formais do texto original. O trabalho criativo é guiado pela qualidade das interpretações destes textos, de tal sorte que, quanto maior a atenção aos aspectos poéticos - justamente, aqueles de mais difícil tradução - mais sugestões para estimular um pensamento formulado pela apreensão de similaridades, pela associação de ideias ou por analogias, em um processo de síntese próprio do pensamento projetual. Assim, a tradução intersemiótica é, nada mais, que uma estratégia pedagógica para o ensino de projeto oferecida, pontual e individualmente, no momento de encerramento do curso de graduação em Arquitetura e Urbanismo na FAU-USP.

\section{Referências biliográficas}

ANDRADE, Mário. De Paulicéia Desvairada a Café (Poesias Completas). São Paulo: Círculo do Livro, 1986

BARBOSA, J. Alexandre. As Ilusões da Modernidade. S. Paulo, Perspectiva, 1986.

A lição de João Cabral. In Cadernos de Literatura Brasileira nº. 1, março de 1996. S. Paulo, Instituto Moreira Salles.

CALVINO, Italo. O Visconde Partido ao Meio. São Paulo, Cia. das Letras, 2012.

CAMPOS, Haroldo (organizador). Ideograma: Lógica, Poesia, Linguagem. São Paulo, Cultrix, 1986.

DUBOIS, J.; EDELINE, F; KLINKENBERG; J. M.; MINGUET, P.; PIRE, F.; TRINON, H. Retórica geral. São Paulo, Cultrix / Edusp, 1974.

DUCROT, O. e TODOROV, T. Dictionnaire encyclopédique des sciences du langage. Paris, Seuil, 1972.

FERRARA, L. D’Aléssio. Estratégia dos Signos. São Paulo, Perspectiva/Secretaria de Estado da Cultura, 1981.

GULLAR, Ferreira. Poema Sujo. Rio de Janeiro, Editora Civilização Brasileira, 1979.

HERNÁNDEZ, Felisberto. O Cavaleiro Perdido e Outras Histórias. São Paulo, Cosac Naify, 2006.

JAKOBSON, R. Linguística e Comunicação. São Paulo, Cultrix, 1985.

JORGE, L. A. A teia e o rio. Volume I. Memorial Circunstanciado de Livre Docência, FAU-USP, 2016.

KAFKA, Franz. Um Artista da Fome / A Construção. São Paulo, Cia das Letras, 1998.

A Metamorfose. São Paulo, Cia das Letras, 1997.

MACHADO, Antônio de Alcântara. Laranja da China. São Paulo, Edição Fac-símile IMESP / DAESP, 1982.

MARQUEZ, Gabriel Garcia - A Incrível e Triste História de Cândida Erêndira e sua Avó Desalmada. Rio de Janeiro, Editora Record, 1972. 
MELO NETO, J. Cabral. Obra Completa, vol. único, Rio de Janeiro, Nova Aguilar, 1994.

PEIRCE, C. S. Semiótica e Filosofia. São Paulo, Cultrix, 1983. Semiótica - São Paulo, Perspectiva, 1977.

PEREC, Georges. Un homme qui dort. Paris, Editions Denöel, 1967

PIGNATARI, D. Semiótica e literatura. São Paulo, Cortez e Moraes, 1979. Informação linguagem comunicação. São Paulo, Cultrix, 1981. Semiótica da montagem. In Revista Através. São Paulo, Martins Fontes, 1983.

PLAZA, J. Tradução Intersemiótica. São Paulo, Perspectiva, 1987.

PRADO Jr, Bento. Alguns Ensaios: filosofia literatura psicanálise. São Paulo, Max Limonad, 1985.

QUEIRÓS, Bartolomeu Campos de. Vermelho Amargo. São Paulo, Cosac Naify, 2011.

ROSA, J. Guimarães. Primeiras Estórias. Rio de Janeiro, Livraria José Olympio Editora, 1967.

SÁNCHEZ, Alberto Ruy. Los Jardines Secretos de Mogador. México D. F., Punto de Lectura, 2004.

SCHIGA, Naoya. A Morte da Mulher do Atirador de Faca. In Mar de Histórias, Antologia do Conto Mundial VIII - No Limiar do Século XX. Organização: Ferreira, Aurélio Buarque de Holanda e Rónai, Paulo. Rio de Janeiro, Nova Fronteira, 1986.

SILVA, Agostinho. Ensaios sobre Cultura e Literatura Portugues e Basileira - Volumes I e II Lisboa, Âncora editora, 2000.

STEINBERG, Saul. Reflexos e Sombras. Rio de Janeiro, Instituto Moreira Sales, 2011.

VALÉRY, Paul. Variedades. São Paulo, lluminuras, 1991. 